NBER WORKING PAPER SERIES

\title{
OPENING ACCESS: BANKS AND POLITICS IN NEW YORK FROM THE REVOLUTION TO THE CIVIL WAR
}

\author{
Howard Bodenhorn \\ Working Paper 23560 \\ http://www.nber.org/papers/w23560 \\ NATIONAL BUREAU OF ECONOMIC RESEARCH \\ 1050 Massachusetts Avenue \\ Cambridge, MA 02138 \\ June 2017
}

I thank Ray Cohn, Nathaniel Donahue, and participants at 2017 Tobin Project conference for comments on an earlier draft, the New York State Library and Archives and the interlibrary loan service at Clemson University for their assistance in locating materials, and Pam Bodenhorn for her help in matching director and legislator lists. The views expressed herein are those of the author and do not necessarily reflect the views of the National Bureau of Economic Research.

NBER working papers are circulated for discussion and comment purposes. They have not been peer-reviewed or been subject to the review by the NBER Board of Directors that accompanies official NBER publications.

(C) 2017 by Howard Bodenhorn. All rights reserved. Short sections of text, not to exceed two paragraphs, may be quoted without explicit permission provided that full credit, including (C) notice, is given to the source. 
Opening Access: Banks and Politics in New York from the Revolution to the Civil War Howard Bodenhorn

NBER Working Paper No. 23560

June 2017

JEL No. N21,P16

\begin{abstract}
$\underline{\text { ABSTRACT }}$
Before 1838 commercial banks in New York, as elsewhere, were incorporated by special legislative charter. In 1838 New York adopted free banking, which transformed bank formation from legislative prerogative to administrative procedure. This paper places this transition within the context of the North, Wallis, and Weingast (2009) model of social transitions from natural states to open access orders, and shows that the transition was more process than discrete event. A confluence of events, including the expansion of the franchise under the 1821 constitution, the emergence of party machine politics under the direction of Martin Van Buren, and the rise of the opposition Antimasonic Party, brought patronage-based politics and the political disbursement of economic privileges under attack. Pre-1838 attempts to open access to finance were turned back by natural state politicians, who used the chartering process to reward party operatives. By the mid-1830s, public distaste for spoils-driven patronage generated pressure to expand access to bank finance, especially among entrepreneurs in southern and western New York frustrated by their limited access to transportation and financial networks. New York's adoption of free banking then was not an ill-advised response to the panic of 1837, but rather a manifestation of a longer-term process toward a more open polity and economy.
\end{abstract}

Howard Bodenhorn

John E. Walker Department of Economics

College of Business

201-B Sirrine Hall

Clemson University

Clemson, SC 29634

and NBER

bodenhorn@gmail.com 


\section{Introduction}

Prior to the adoption of free banking in 1838, commercial banks in New York, as elsewhere, were incorporated only by specific legislative charters. General incorporation laws had been adopted for religious and educational organizations and for certain manufacturing firms, but New York's free banking act was one of the first durable general incorporation acts to establish the practice of legislatures delegating incorporation to administrative authorities. New York's free banking act was important not just for its monetary and banking implications for the remainder of the nineteenth century, but because it established a precedent for transforming business incorporation into a purely administrative act free of political considerations. Hammond $(1957,572)$ interprets the term free in free banking to mean free of most salutary economic restrictions and regulations, and modern banking historians (Rockoff 1974; Selgin and White 1994) interpret it to mean relatively free entry. This article argues that it might be better interpreted as an attempt to free it from its checkered history of political machination and manipulation.

One question without a satisfactory answer is why free banking was adopted when it was. Hammond (1957) and Redlich (1968) contend that free banking resulted from a confluence of a long-term trend of increasingly laissez-faire economic policies and a short-term inflationist response to the panic of 1837. Bodenhorn (2006) argues that it was culmination of a reformist impulse in which the panic finally galvanized an electorate that was no longer tolerated the corruption involved in bank chartering, specifically, and the dispensation of economic privileges, more generally. Neither explanation appears to appreciate the long-term process of change.

North, Wallis, and Weingast (2009) develop a conceptual framework of the connection between politics and economics that offers an alternative interpretation of free banking. Their natural state-open access approach subsumes both Hammond's laissez-faire and Bodenhorn's corruption interpretations. In the North, Wallis, Weigast scheme, a natural state is one in which government generates and 
distributes rents to a ruling coalition of elites. One of the most important of the rentcreating privileges extended by the state to favored coalitions is the privilege of forming political, social, and economic organizations that will be supported and protected by the state. Because the long-term success of the corporation as a business enterprise depends on third-party (government) enforcement of contractual relationships, the distribution of rents through the aegis of the corporation provides a credible mechanism of rewarding and disciplining elites (North, Wallis, and Weingast 2009, 20). Moreover, the state's singular ability to enforce organizational contracts induces cooperation among the elite because durable organizations increase the returns to inputs.

Lu and Wallis (2017) depict early-Federalist Massachusetts banking policy as a representative case of the natural state. Banks were important rent-generating mechanisms, and the ruling coalition integrated bank chartering into a political patronage system to solidify their control over the political apparatus. Up to 1811 Federalists controlled the Massachusetts legislature and were able to translate that control into a virtual Federalist monopoly on banking. Federalist control of the financial sector mattered for the wider business world because, in a credit-scarce environment, Federalist bankers rationed credit in a way that favored Federalist merchants. ${ }^{1}$ When Republicans took control of the legislature and the governorship in 1811, they chartered new banks to serve the Republican elite. Moreover, the charters of the Federalist banks were due to expire in 1812, and the now-ruling Republicans threatened Federalist rents by threatening not to renew the charters. But the Republicans lost control of the lower house and the governorship in 1812, and the Federalists renewed the charters.

Lu and Wallis (2017) argue that Massachusetts politics could have reverted to the natural state status quo ante after 1812, with Federalist majorities dispensing privileges to Federalists while threatening Republican privileges, and vice versa. Instead, the competing parties appear to have arrived at an implicit understanding in which the future dispensation of bank charters depended more on the economic qualifications of the prospective incorporators and the current state of supply and

\footnotetext{
${ }^{1}$ Lamoreaux's (1999) research reveals that bankers and merchants were sometimes the same; in other instances they were connected by kinship ties.
} 
demand for finance in a community. The result was a rapid increase in banks that helped fuel the state's economic growth.

In the context of the North, Wallis, and Weingast (2006) framework, the post-1812 depoliticization of Massachusetts banking represented a move toward an open access order. Open access orders are those in which control of the political system is contestable through peaceable means. All citizens have the right to form political organizations. Open access orders are also societies in which all, or at least most, citizens have the right to establish economic organizations, namely the business corporation, and have access to the state's enforcement mechanisms to structure internal and external relationships. The right to form such organizations becomes impersonal in the sense that the right to form an organization does not depend on the individual's personality or personal connections (Wallis 2011). Hilt (2017) finds that in the case of manufacturing corporations, the transition from natural state to open access tends to be more process than discrete event, and that the process began in the early nineteenth-century.

This paper reinterprets the evolution of banking policy in New York during the first half of the nineteenth century as a transition from natural state to open access. As in Massachusetts, Federalist-majority legislatures in New York chartered banks to serve Federalists; Republican majorities chartered Republican-leaning banks. Unlike Lu and Wallis, this study is less concerned with the specific political identity of the politicians who chartered banks and the men who ran them than with the long-run decline of the politician-banker. New York's nineteenth-century, natural-state politicians considered bank chartering as an element of their overall patronage system. Politicians rewarded loyal party members with bank shares and bank directorships. In the 1790s, it was not unusual for a bank's original board of directors — appointed by the legislature in the charter — to be made up of politicians. More than one-third of men appointed to the boards of New York's earliest banks served in the state assembly, one-fifth served in the state senate, and one-in-ten served as a state circuit court judge. Bank directorships were highly sought after because appointment conferred the right to a share of the rents generated by the bank. This was the natural state in action. A group of the current ruling elite distributed rents to other members of the elite in support of a coalition. 
In the 1790s New York's competing elites of both parties practiced this behavior and the electorate, which was then less than one-third of the adult male population, accepted it as part of the natural course of political struggle. By the 1820s, however, the electorate included nearly all adult males, new political parties formed, old parties and factions realigned, and economic growth created an emerging class of merchants and professionals eager to take advantage the market opportunities created by new transportation technologies. This emergent class of market-oriented farmers, merchants, and entrepreneurs wanted access to credit, which the partisan-based patronage system failed to deliver. Free banking represented a decisive change, but it was the product of a longer trend toward depoliticizing banks and the disappearance of the politician-banker. Between the 1790s and the early 1830s, just before the enactment of free banking, the share of state assemblymen serving on original boards declined from one-third to one-fifth. Twenty years into free banking it was less than one-eighth. This paper documents the mechanics of early New York's rent-distributing practices and explores the forces underlying its long-run decline.

\section{Natural states and open access orders}

North, Wallis, and Weingast (2009, hereafter NWW) delineate between two principal types of modern political regimes: natural states and open access orders. Most states are natural states. Only a relatively few, mostly western, societies have transitioned to open access in the past millennium, and most of those transitioned in the past two centuries, usually within a relatively brief period. The United States transitioned from a (mature) natural state to open access between about 1800 and 1850, as many states extended the franchise beyond a small group of wealthy landowners to most white males. Of equal importance, states started to extend the right to form organizations, especially the business corporation, to all citizens, though some retained the prerogative to deny controversial organizations free incorporation (Hilt 2017; Bloch and Lamoreaux 2017).

NWW argue that the glue that holds the natural state together is the government's capacity to assign and protect the economic rents generated by limiting 
entry into economic activities to the existing elite. Natural states, notes Wallis (2011, 51), "create individual privileges and rents through social organizations, and use those organizations to bind powerful individuals together into a sustainable coalition." From a modern perspective, the patron-client networks that define the natural state appear inherently corrupt. The entire apparatus of government is constructed around personal relationships. Who one is, who one knows, and an ability to extract concessions, rights, and privileges from the state, more so than what one does, determine who gets ahead and who does not. A focus on the system's apparent corruption, however, misses the point. The state's distribution of rents based on individual personalities (the powerful), personal relations and patronage networks (the connected) maintain order in the natural state. A rent created by the state and allocated to a small, personal group creates incentives for intra- and interelite cooperation rather than conflict, and can induce cooperation among previously uncooperative elites if the rent can be captured only through cooperation.

The fundamental question surrounding natural states and open access orders is how the transformation takes place. If the natural state is designed to create and distribute rents to the elite, why would the elite ever hand over these powers? Why would the elite agree to a system in which non-elites can form organizations and compete away rents previously created and protected by the state? Acemoglu and Robinson (2006, 23-29) contend that the elite opt for more open access when they face a revolutionary citizenry that has solved the collective-action problem. The prospect of revolution creates a choice for the elite between peaceably ceding control and retaining their wealth, or losing both control and wealth during a violent overthrow.

NWW (2009, 27, 149-50) argue that Acemoglu and Robinson's interpretation is based on a model of the elite as a coalition in which interests are aligned within the group. But elites are not unified and their personal interests do not always align with the majority interest. Thus the elite compete among themselves within the boundaries prescribed by the rules of the natural state, and are rarely in a position to intentionally decide to do anything, including share power with non-elites. The transition from natural state to open access then is not a conscious decision to share power with non-elites; rather the transition originates in choices made by the elite to 
adopt more impersonal relations within the elite. Mature natural states create systematic rules for the creation of organizations by and for the elite. Once the elite extend impersonal privileges (primarily the franchise and the right to form organizations) and agree to abide by a rule of law among themselves, the privileges and rule of law are gradually extended to the non-elite but only as the elite become convinced that doing so will not create disorder within the ruling coalition.

At the ratification of its Constitution the United States was transitioning from mature natural state to open access. ${ }^{2}$ Despite contemporary fears of their corrosive effects, political factions, defined by James Madison (Goldman 2008, 49) as groups with interests contrary to the interests of the whole community, formed shortly after ratification and, as Madison predicted, were quick to exploit grants of privilege to gain political advantage. In banking policy, for example, Federalists favored the establishment of banks and tended to use them to the advantage of other Federalist businessmen. In New York the earliest chartered banks-Bank of New York [1791], Bank of Albany [1792], and Bank of Columbia at Hudson [1793]—were unapologetically Federalist (Alexander 1906, 186). Although Republicans were opposed to banks in principle, once in power they established their own banks, like the Manhattan Company [1799], and denied petitions from Federalists wishing to establish addititonal Federalist-oriented institutions. This was corruption in classic Whig theory and there is nothing inherent in mature natural state politics, including early American democracy, to derail such behavior (NWW 2009, 235-36). The same sequence of pro-Federalist then pro-Republican bank chartering played out in Pennsylvania, Virginia and elsewhere (Schwartz 1947; Crothers 1999).

In banking, the transition from natural state to open access is marked by passage of free banking laws in eighteen states between 1837 and 1860 and a liberalization of legislative chartering in many others (Rockoff 1974; Rolnick and Weber 1983; Sylla, Legler and Wallis 1987). The elimination of special charters of incorporation and their replacement with general incorporation procedures was not a sudden post-1835 revelation for the proponents of free banking. In 1825 the New York state senate considered a bill that would have repealed the restraining acts that

${ }^{2}$ Koyama (2017) traces the development of England's transition from natural state to liberal order from the Magna Carta forward. 
forbade private banking in the state—a first step toward free banking (New York Senate 1825). The original 1829 bill that established New York's Safety Fund system included a provision that would have liberalized entry, though the provision was removed from the bill's final version (Hammond 1844). In the 1830 s political columnist William Leggett argued in favor of a general incorporation law on the grounds that it would "confer no exclusive or special privileges" (quoted in NWW 2009, 240). Richard Hildreth $(1837,50)$ advocated the abandonment of special charters because they were a "fruitful source of the bitterest party hostilities." Even William L. Marcy, the Bucktail governor of New York to whom is credited the now (in)famous line concerning the victor and the spoils, made common cause with moderate Bucktails, former Clintonians, and Anti-Masons in passage of the state's 1838 free banking law (Spencer 1959, 93). The remainder of this paper offers an interpretation of the first fifty years of New York banking history consistent with the NWW natural state-open access interpretation of history.

\section{Bank chartering in a natural state: New York, 1791-1838}

The principal type of information used to better understand the connection between banks and politics and New York's transition from natural state to open access is the political activity of bank directors. In a natural state, a particular coalition can control the apparatuses of state only so long as they can remain the dominant coalition among the elite. One mechanism for currying favor and maintaining control is distributing rents to certain groups, such as the Federalist policy of chartering banks to be controlled by and for other Federalists. Lu and Wallis (2017) document how the Federalist-Republican contests in early nineteenthcentury Massachusetts altered the political composition of bank directors. This paper adopts a related strategy in that it documents the political participation of bank directors, but without reference to party affiliation. Evidence that banks chartered under a Federalist regime were Federalist and banks chartered under a Republican regime were Republican is evidence of a mature natural state; peaceful political transitions changed the groups who might capture government-created rents. The transition to open access, by comparison, should manifest itself in the 
depoliticization of bank chartering more generally. That is, one piece of evidence consistent with increasingly open access will be a decrease in the fraction of the politically-connected elite involved in the creation and management of economic organizations. Information on the political connectedness of bank directors provides insights into the nature and timing of the transition to open access because bank charters were valuable and bank directors were visible.

\subsection{Data: Original bank directors, subscription commissioners, and petitioners}

The principal type of evidence used to study the connection between banking and politics is lists of the initial directors of newly chartered banks. The chartering act authorizing the pro-Federalist Bank of New York, whose original articles of association were drafted by Alexander Hamilton, was typical in that Section 5 of the act listed the men who would serve as directors until the first shareholder election (New York 1802, 351-55). The bank's charter named 13 men as its first directors, among them Isaac Roosevelt, who served 13 years in the state senate and three terms on the state's Council of Appointment, Gulian Verplanck, who served nine years in the state assembly and four terms in the U.S. House of Representatives, Comfort Sands, four-term assemblyman and one-term state comptroller, John Murray, judge, and William Maxwell, who served for seven years as state district attorney (Hutchins 1870). The men named in the charter of the staunch-Federalist Bank of Albany in 1792 included, besides Jeremiah and Stephen Van Rensselaer, men who had or would later serve as state senators, assemblymen, congressmen, and as state surveyor (Weise 1884, 431). Republican-chartered institutions were similar. The Manhattan Company's original directors included judges, state senators, assemblymen as well as an attorney general, a future congressman, and Aaron Burr, a future Vice President of the United States. Thus the men allowed to establish and manage the state's banks were drawn disproportionately from the political-economic elite. Because bank directors were well positioned to benefit from the rents distributed by the organization to its managers and owners, ruling groups used bank directorships as rewards for past loyalty to, as well as inducements for continued effort on behalf of, the coalition. 
The first step of data collection involved collecting nearly every New York bank charter between 1791 and 1836, the last year in which the legislature provided special acts of incorporation. ${ }^{3}$ In addition to original directors, charters sometimes provided the names of the principal petitioners for the charter, and the commissioners appointed by the legislature to solicit subscriptions for bank shares, distribute the shares among the subscribers, and collect the initial payments for shares. Of the 2,333 individuals included in the sample, there are only three cases in which the same man served as a petitioner, commissioner, and original director. In 42 instances, a petitioner serves as an original director; and in 37 instances a subscription commissioner is also a director. Eighty-six men served as the original director on more than one bank, most of which opened in the 1850s; 16 served as subscription commissioner for more than one bank; a single man, Selah Reeve of Newburgh, appeared on more than one petitioner list.

In the $1830 \mathrm{~s}$ it became more common for chartering acts to include the names of the subscription commissioners without a list of the men appointed to serve as the original directors. The reason for this change is not clear. It may have been that the legislature believed it was appropriate to delegate the selection of original directors to the shareholders, or it may have been that the legislature simply chose to omit this information from the charters. Moreover, after 1837, the state could no longer issue special charters of incorporation, so the names of the original directors of some chartered and all free banks in the sample are reconstructed from city and county histories, which often contain detailed director lists of local banks. ${ }^{4}$ In other cases, original director lists are taken from published bank histories. A data appendix provides a detailed list of sources. The final sample includes 1,789 bankdirector observations (86 men served on the original board of more than one bank), 593 bank-commissioner observations, and 125 bank-petitioner observations.

The sample of director-commissioner-petitioner names was matched to the lists of men who ever represented New York State in a state or federal office. The

3 Of the banks listed in Weber's (2006) bank census, four early bank charters could not be located.

4 The city and county histories are not a random sample; a city, county, or bank history is used if it is available on Google Books. I started searching for director lists in larger, more populous counties and then continued to search alphabetically by county for original director names until the sample included about 2,500 person-years. 
New York Civil List (Hutchins 1870) provides the names of every individual who served as a county or state judge, a state senator or assemblyman, on the state's Council of Appointment or Council of Revision, as a U.S. Congressman, or in some other administrative position, including governor, lieutenant governor, state comptroller, among several other official positions. A director-commissionerpetitioner is considered to be among the political elite if they ever served in an office listed in Civil List. Thus, the definition of political elite is inclusive, in that it includes men who served in lesser offices and men that served only a single term in any office. Moreover, the director-commissioner-petitioner is counted as match if they ever served in an appointed or elected governmental office, regardless of whether it was before, during, or after their bank affiliation.

\section{$<$ Table 1 about here $>$}

Table 1 reports the number of observations and the nature of public service of bank directors, subscription commissioners, and petitioners by decade. The number of observations by decade is consistent with cycles of new bank formation (4 banks formed in the 1790s; 5 in the 1800s; 24 in the 1810s; 13 in the 1820s; 122 in the 1830s; 108 in the 1840s; and 248 in the 1850s), although the 1820s are overrepresented and the 1840s under-represented in the original director sample (Weber 2006). Panel A reveals a long-run decline in political participation among original bank directors. In the 1790 s, $9.8 \%$ of original bank directors served as an appointed or elected officer of the court (judge or sheriff) at some point in their careers. Nearly $20 \%$ ever served in the New York state senate; more than one-third served in the state assembly, and 3.9\% served in Congress. After free banking was implemented in 1838, no original bank director ever served as an officer of the court or was elected to U.S. Congress; fewer than 3\% served in the state senate and the fraction who ever served in the state assembly declined by two-thirds.

Up to the implementation of the free banking, men actively engaged in politics were subscription commissioners (during the free banking era, there were no legislatively appointed commissioners). Panel B of Table 1 shows that nearly $40 \%$ of commissioners for banks chartered in the 1810s ever served in the state assembly; in 
the 1820 s and 1830 s between one-fifth and one-fourth of commissioners ever served in the assembly. A smaller but nontrivial fraction served in other appointed or elected offices. Service as a commissioner, as discussed in section 4.3, was about political connections and serving the political ends of the natural state, namely allotting shares to political allies. Legislative appointments of commissioners served the natural state, as well, because appointment offered a lucrative reward to the party faithful. The only compensation for the time and trouble for service as a commissioner was the right to subscribe to shares, typically capped at 25 , which was more than most successful subscribers were allotted. Because shares often sold at 10 to $20 \%$ above their offering price (par value) within days of distribution, obtaining a commission was a potentially lucrative appointment.

Service as a commissioner was not for the faint-hearted, however. Because nearly every share subscription in the 1820s and 1830s was over-subscribed, it fell to the commissioners to allocate shares among the subscribers. Unlike Pennsylvania, which imposed a pro rata rule (every subscriber received at least one share and any remaining shares were allocated in proportion to shares subscribed), New York left the allocation of shares to the discretion of the commissioners. Aspiring shareholders lobbied on their own behalf between subscription and distribution days. Disappointed subscribers brought suits against commissioners and demanded legislative investigations. Opposition legislators formed investigating committees. Commissioners were deposed. They were called to testify before legislative committees. Committees sometimes published verbatim transcripts of the hearings (see, for example, New York Assembly 1838). Opposition newspapers republished testimony to expose the commissioners for their blatant partisanship.

Panel C of Table 1 reports available information on petitioners whose petitions resulted in a charter. The petitioner data will not be analyzed in detail because it is a small and selective sample in that it does not provide any information about petitioners whose charter requests were rejected by the legislature. The extant evidence, however, is consistent with the politicization of bank chartering. Between 1800 and 1836, approximately one-fifth of successful petitioners ever served in the state assembly. Lesser fractions ever served in other elected and appointed offices. 


\subsection{Data: New York City bank directors, 1800-1860}

A second type of data collected to trace the transition from natural state to open access is lists of bank directors at New York City's banks. These data include all director-years, not just the original directors at newly established banks. Unlike Lu and Wallis (2017), who exploit an annually published survey for their study of Boston's bankers, there is no consistent source of information on New York's bank directors for the period between 1800 and 1860. Thus, the data is compiled from several sources and only for select years. The data appendix provides a complete list of sources.

Between 1800 and 1815, the data are drawn mostly from city directories, which provided a complete list of current directors. Beginning with the 1820s, the directories become less useful because they tend to report only the names of bank presidents and cashiers. Directors are not listed, but the names of presidents are included in the sample to provide some information on political participation. Given the demands on a bank president of daily attendance at the bank, however, it is likely that presidents were less politically active than other directors at least during their terms as bank presidents. Williams $(1835 ; 1840)$ provides complete director lists, as do Wilson (1845; 1849; 1856) and Belden (1851). These data are further supplemented by director lists provided in bank histories. The resulting data set contains complete director lists for 1801, 1805, 1808, 1813, 1815, 1835, 1840, 1844, 1848, 1851, and 1856, and partial lists for 11 years between 1822 and 1857. The 1820 s are a potentially important data lacuna.

$<$ Table 2 about here $>$

Table 2 reports statistics by decade of board service on the share of directoryears by directors who ever served in the New York state senate or assembly. (Given the small proportions of original directors who served as court officers or Congressmen, New York City directors were not matched to these series.) As with the original bank directors, there was a declining fraction of directors who ever served in political office. Between 1800 and 1809, 20.3\% of the 202 director-years are associated with at least one term in the state senate; $25.7 \%$ with at least one term 
in the assembly. In the 1850s, by contrast, director-years associated service in the senate falls to $0.4 \%$ and to $3.3 \%$ for ever served in the assembly. Consistent with Hilt's (2017) finding that opening access is a process rather than a discrete event, the series decline continuously from 1800 to 1859, though there is a marked decline in the senate and assembly series in the 1820 s.

\section{New York banking: three regimes}

The history of banking in New York between the ratification of the Constitution and the American Civil War can be divided into three regimes. ${ }^{5}$ The first, from 1791 to 1812 was one in which relatively few bank charters were granted. When they were, they were handed out on purely political grounds. The second period runs to 1825, during which time overt bribery fell from favor and the share of politician-bankers declined, especially among New York City's banks. The third period, 1825 to 1838, were the years of Bucktail ascendancy in New York, and was one in which the dominant Democratic faction transformed chartering from a process by which individual legislators enriched themselves to one in which chartering served the Bucktails' ends. Chartering became pure patronage. And the fourth period, or free banking era, represented one of New York's early steps toward a more open access order.

\subsection{The early republic as a natural state, 1791-1824}

In his political history of New York, Alexander (1906, 186) provides a traditional interpretation of early bank chartering: Federalists were pro-bank and mobilized their banks' resources to the advantage of Federalist businessmen. Republicans were opposed to banks in principle, but recognized the "political necessity" of having Republican banks capable of offsetting the influence of Federalist financial institutions. The state's first three banks were known to be

\footnotetext{
${ }_{5}^{5}$ Moss and Brennan (2001) adopt a slightly different three regime delineation in their analysis of antebellum New York banking based on the regulatory system - chartered banking (1784-1829), the Safety Fund system (1829-1837), and Free Banking (1838-1863). The delineation adopted here is based more on the political structure and how politics influenced bank chartering than on the specific regulations of the era. There is, not surprisingly, substantial overlap between the political and the regulatory regimes.
} 
Federalist in orientation. The first Republican-controlled bank was the Manhattan Company, a water company that assumed banking privileges under a clause in its charter that allowed it to employ any excess capital in "moneyed" activities. The directors used that clause to establish a banking affiliate, and soon became more bank than water supplier. Aaron Burr, one of the driving forces behind the company, viewed it as a counterweight to Alexander Hamilton's Bank of New York.

But as NWW (2006, 149-50) hypothesize, the interests of the elite were not always aligned within that group. After Burr lost the 1800 presidential election to Thomas Jefferson, De Witt Clinton and Brockholst Livingston realized that Burr's fall from favor within the party cleared the way for them to take control of the Manhattan Company. Burr, his close friend and political ally John Swarthwout, and other Burr allies were replaced on the bank's board of directors by Livingston and other Clinton supporters, who could now capture and distribute the bank's rents to their allies. Control of an important organization, then, afforded one faction within the political elite the capacity to reward and discipline the in-group and punish the out-group.

The contest for political office and bank charters played out across the state. The management of the Bank of Albany was unfavorably disposed to the interests of some of the city's merchants and manufacturers so that, in 1803, when the projectors of the New York State Bank published their prospectus, they proposed "a true republican institution" (Weise 1884, 431). Thus the second bank at Albany was born in 1803 to serve a Republican clientele. Contemporary observer and political historian Jabez Hammond $(1844,194)$ considered the idea of a Republican bank as absurd as Republican wheat, corn, air, or water, but banks were different and a bank committed to a party was a valuable engine for distributing rents.

It is understandable why a Republican merchant would support a Republican bank; the puzzle is why a Republican politician who professed anti-bank principles would and could support a bank without alienating his anti-bank, anti-Federalist constituents. The answer lies in the logic of the natural state. Republicans needed a mechanism by which rents could be distributed among the ruling elite consistent with enhancing the party's attraction to the elite. One way, as in the case of the Manhattan Company, was through a directorship. But there were fewer available 
director positions than members of the elite. Moreover, some wanted to profit from bank chartering but possessed neither the skills nor the inclination to be a bank director.

To guarantee the bank's Republican bias and induce legislators to vote for its charter the organizers promised shares to Republican legislators. Thus began a practice that persisted in various guises for the next three decades (Hammond 1844, 329). The legislators could hold the shares, if they wanted to maintain a connection to the bank, or sell them, if they preferred a quick profit. Soon after the bank's opening, shares typically traded at premium over the issue (par) price, so the profits could be substantial. As Alexander $(1906,188)$ notes, a legislator fortunate enough to be offered the deal received "a gift of ten or twenty dollars on each share" and members clamored, "intrigued, and battled for the stock." No one took exception to the corruption. Even Erastus Root, one of New York's Republican representatives in Congress in 1803, saw nothing improper in the dealings. "No one would hesitate from motives of delicacy," wrote Root, "to offer a member, nor for him to take shares in a bank[,] turnpike, or ... canal" (quoted in Alexander 1906, 188). Root's principal complaint was that the bank's organizers promised him 50 shares, but gave them to another. Decades later he still had not forgiven his fellow Republicans. To modern readers the entire episode appears deeply corrupt, but it was a mechanism for the elite to distribute a bank's expected rents among the elite; it was used to tie individuals to factions within the natural state.

Figure 1, which plots the fraction of original directors who ever served in the New York senate or assembly, reveals that a remarkable number of state senators and assemblymen held onto the shares they were awarded in the share distributions and were elected to directorships. Between 1790 and 1810 about 40\% of original bank directors served in the state assembly at some point during their careers; approximately 20\% ever served in the state senate. After 1810 the proportion of directors that ever served declined, though the fraction varied between zero and $33 \%$. The fraction of initial directors that served in the state senate was also halved between the 1800s and 1810s. The decline in the politician-banker reflects the depoliticization of banks documented by Lu and Wallis (2017). 
There were many reasons to own bank shares and seek directorships. Banks were profitable and distributed dividends, of course, and the insider nature of bank lending meant that ownership placed potential borrowers at the head of the queue (Lamoreaux 1999). Of equal importance, perhaps, was that a place on the board gave the legislator a voice in who borrowed, how much they borrowed, and for what purpose. A directorship was a potentially powerful political tool. Partisan directors were well positioned to direct credit to politically favored economic elites.

Figure 1

Percent of initial bank directors at new banks to ever serve in the state assembly or senate

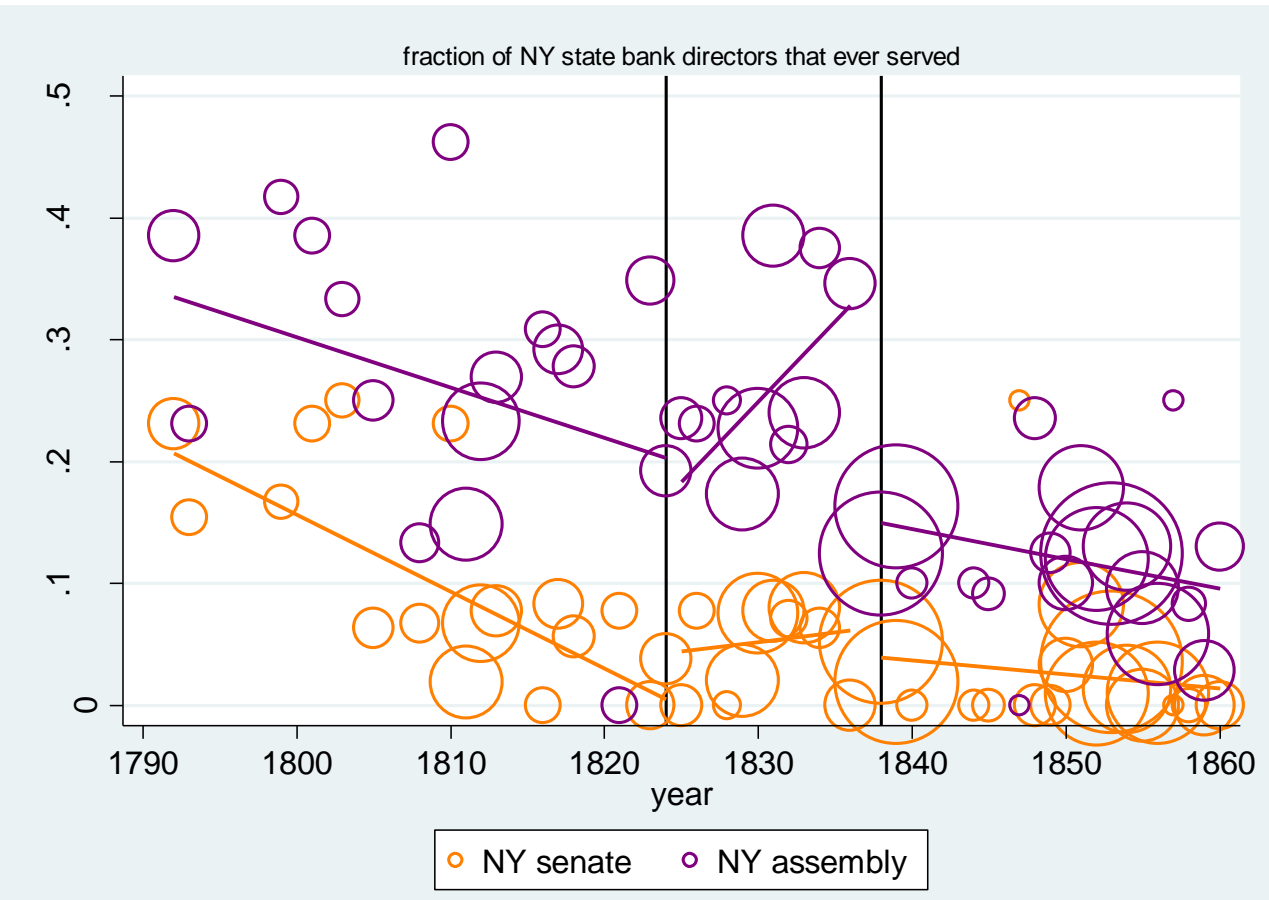

Notes: circle size proportional to number of observations per year. Sources: author's calculations from sources in Data Appendix.

A second event that defined natural-state bank chartering policy occurred in 1803. A group of Federalists joined in partnership to establish the Merchants Bank in New York City. Not only was their 1804 petition for a corporate charter rejected, the 
Republican dominated legislature passed an act that prohibited unincorporated banking. The 1804 restraining act protected existing and future rents in banking. The Merchants Bank was given until May 1805 to wind up its affairs. In early 1805 the bank's partners again petitioned for a charter, which was initially rejected based, according to Hammond $(1844,219)$, "on party grounds, not because chartering the bank would be prejudicial to the public interest." When it became clear that the petition foundered in committee, the bankers solicited the help of state senator Ebenezer Purdy. A subsequent legislative investigation produced affidavits from a six legislators who testified that they were promised as many as 50 shares that would be repurchased at $\$ 20$ to $\$ 25$ over par in return for vote in favor of the charter (Alexander 1906, 190-91; Benton 1856, 386-87). Legislators who opposed the charter on principle testified that they were offered shares to absent themselves on the day of the vote.

The Merchants Bank received its charter. Every aye vote was suspect. Ebenezer Purdy was forced to resign from the senate. Ambrose Spencer, state supreme court justice, and Erastus Root, who had no issues with similar practices surrounding the New York State Bank charter, considered the Merchants Bank affair sordid and "downright" corrupt (Alexander 1906, 191). To modern sensibilities it was. But the corruption surrounding the Merchants Bank's charter reveals an evolution in attitudes and the operation of the natural state. Jabez Hammond (1844, 221), Republican state senator, Congressman, university regent, county court judge, and political historian, recalls favoring the petition because even Federalists "ought [not] be deprived of the right to using their money for banking purposes." Although the Federalists behind the Merchants Bank might use the bank to the advantage of Federalists, a Republican legislature could, by approving the charter, extract a sizeable fraction of the bank's rents for its own members. They had also restrained unauthorized elites and non-elites from dissipating the rents of existing and future banks. Thus, Federalists would approve deserving Republican proposals and Republicans would approve deserving Federalist proposals, but not without receiving something in return. The interests of the elite were not, strictly speaking, aligned. They had, however, come upon a mechanism for building coalitions capable of generating and distributing rents among themselves. 
The system of legislators lining their own pockets from bank charters reached its apogee in 1812. When Congress failed to renew the charter of the Bank of the United States in 1811, prospective bankers in most of the country's principal cities, including New York City, scrambled to capture the profits previously earned by the Bank. One group of New Yorkers petitioned for an institution to be called the Bank of America with a capital of $\$ 6$ million, which was three times the size of the city's largest existing bank. In return for the 30-year charter, the prospective bankers promised to pay $\$ 400,000$ per year for four years into the state treasury. If no other banks were chartered in New York City for the next 10 years, it would pay another $\$ 100,000$, and an equal amount at the end of 20 years if no other was chartered. In addition it promised to lend another $\$ 1$ million at $6 \%$ interest to finance canal construction. It would lend another $\$ 1$ million to farmers on mortgage (Hubert 1903, 89; Hammond 1957, 162). In return for a charter the proposed bank promised to distribute its rents beyond its shareholders.

The petitioners hired two prominent Republicans, David Thomas and Solomon Southwick, and others to lobby on its behalf. Thomas was a long-time friend of De Witt Clinton. Jabez Hammond $(1844,300)$ described Thomas, a fourterm Congressman, former assemblyman, and state treasurer with wide connections, as "a silent, cautious man, artful, sagacious, and possessed of a deep knowledge of men." Southwick, editor of the Albany Register, then the most influential Republican newspaper, was handsome, likable, persuasive, equally well-connected, and expected to attain high public office (Alexander 1906, 192-93). Both men used their connections, promises of shares in the bank, and cash to convince legislators to vote for the charter, while men representing the existing banks lobbied against it. When word of the bribery reached Governor Daniel D. Tompkins, an "orthodox" Republican opposed to the establishment of new banks, he invoked his constitutional prerogative to temporarily dismiss the legislature for six weeks (Benton 1856, 359; Hammond 1957, 163). When the legislators reconvened the charter passed easily. Charges of vote buying later led to several indictments. Lobbyist John Martin served time in the penitentiary for his attempts to bribe legislators. Although Thomas and Southwick were acquitted in separate trials, the episode derailed their 
political careers, as well as the presidential aspirations of their friend and ally De Witt Clinton.

Historians tend to portray the Bank of America episode as one in which Federalist bankers corrupted Federalists and Republicans alike. The promises were sufficiently lucrative that only the most principled Republicans withstood the temptations of shares or cash. While many men surely stood by their principles, the most outspoken opponents of the bank's charter did not come from "orthodox" anti-bank, anti-corporation Republicans, but rather from Republicans with an interest in the Republican-controlled Manhattan Bank and New York State Bank. David Thomas was arrested and tried based on a warrant issued by Judge Ambrose Spencer, who acknowledged that his opposition to the Bank of America was motivated by the fact that his shares in the Manhattan Bank were likely to decline in value if the Bank of America opened. In an opinion rendered as a member of the Council of Revision, Spencer objected to the Bank of America's charter because it threatened to "impair the security of every bank" and the property of individuals “may be depreciated, if not endangered" (Street 1859, 433). Republican shareholders in the State Bank expressed similar concerns. Thus, the opposition to the Bank of America flowed as much from a desire to protect previously awarded rents as from political principle.

Figure 2, which plots the fraction of directors at all New York City banks who ever served in the state legislature, reveals the consequences of the Bank of America scandal. While the fraction ever serving in the state senate declines by about five percentage points between 1791 and 1811, the fraction ever serving in the assembly increases by approximately 20 percentage points, from about $10 \%$ to $30 \%$ of board members. Despite the brouhaha surrounding the Bank of America's charter, City Bank (now Citi) and the New York [City] Manufacturing Company Bank had proportionately more politically active men on their original board of directors. After the Bank of America chartering scandal, the trend toward electing politically active men to the board reverses. In the 13 years after 1811, the percentage of legislators serving on bank boards declines from approximately one-in-three to about one-in-five. 
Figure 2

Share of New York City Bank directors that ever served in state assembly or senate

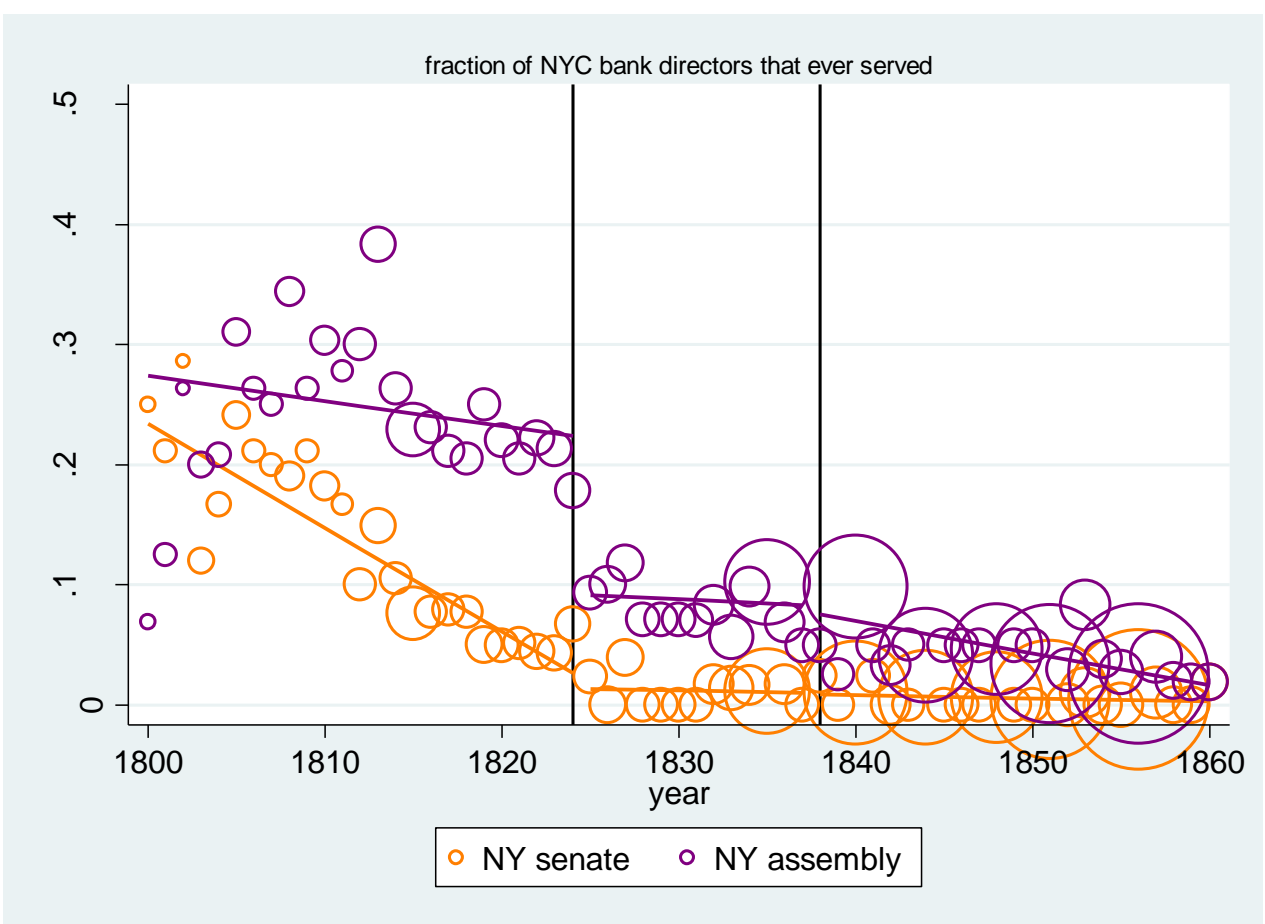

Notes: circle size proportional to number of observations per year.

Sources: author's calculations from sources in Data Appendix.

One explanation for the declining share of politically active board members after 1811 is the slow decline of the Federalist Party as a meaningful challenger to Republicans after the War of 1812. Once the discussions at the Hartford Convention (1814) became public, the Federalist Party faced a crisis of legitimacy from which it never truly recovered. But the decline in politically active directors occurred at Republican and Federalist banks alike. While the fraction of legislators on the boards of the Federalist-oriented Bank of New York and Merchants Bank declined from $30 \%$ in 1812 to $18 \%$ in 1825, the fraction at the Republican-leaning City Bank declined from $40 \%$ to $6 \%$. Thus, after the 1812 Bank of America scandal, it appears that either the value to a bank of having politically active men on the board of 
directors declined or the value to politicians of being on a board declined or both. The extant evidence provides few insights into the motivations and mechanics of the post-1812 change. Hammond $(1844,337)$ argues that the published accounts of the Bank of America investigation disgraced so many legislators and lobbyists that it deterred similar behaviors during the subsequent decade. Whether the scandal fundamentally changed behaviors or whether the corruption surrounding the next several bank charters did not rise to a level to warrant special investigations is difficult to determine.

\subsection{Constitutional change and the Chemical Bank scandal}

Despite a near decade-long period without a bank chartering scandal, memories of the earlier scandals colored subsequent behaviors. Delegates to the 1821 constitutional convention responded by including a clause that required a twothirds majority of both houses of the legislature to charter a bank. The stated purpose of the clause was to limit bribery and ensure that only worthy applicants received charters. It was likely to have the opposite effect, however. If more votes were needed to pass an act, more legislators needed to be convinced of an applicant's merits or compensated or both. The two-thirds requirement raised the stakes, which became evident with the public scandal surrounding the charter of the Chemical Bank.

The New York Chemical Manufacturing Company was incorporated in 1823 to manufacture nitric acid, muriatic acid, paints and dyes. Its original charter expressly forbade it from engaging in banking activities. In 1824, the company's directors petitioned to modify its charter so that it could also operate as a bank. William Caldwell, of New York City, was hired by John C. Morrison, one of the company's directors, to secure its banking charter. A scandal and legislative investigation followed. According to Caldwell's affidavit, Morrison agreed to pay Caldwell $\$ 2,000$ if he was successful in obtaining the charter by "fair and honorable means" (New York Senate 1824, 499, emphasis in original). Caldwell contended that he neither offered nor paid any bribes and, except for three individuals, was convinced that none had been requested or received. One exception involved assemblyman Spencer. According to Caldwell's affidavit, Spencer planned to absent 
himself from the assembly hall on the day scheduled for the Chemical's bank charter vote. Spencer was opposed to banks and, besides, needed to be away on business to raise money to meet his engagements. When Caldwell informed Morrison of Spencer's intended absence, Morrison said if the question was about money that Morrison would provide it, conditional on Spencer's vote and on Spencer using whatever influence he had on the senate vote. Spencer voted for the bank and lobbied on its behalf in the senate. In a subsequent conversation with Caldwell, Spencer is alleged to have revealed that Morrison promised him $\$ 300$ for his vote, but had as yet paid only $\$ 40$. Spencer inquired into whether Caldwell believed that Morrison would make good his promise.

Morrison denied the charges. He denied that he met with Spencer the evening prior to the chartering vote. He denied that he promised Spencer money. He denied that he extended Spencer a loan to influence a vote. Morrison claimed, however, that Caldwell had asked for $\$ 40$ to be paid to an unnamed individual. Spencer later approached Morrison, informed Morrison that he needed $\$ 300$, and asked that Morrison advance him that amount on note (loan). After inquiring into Spencer's affairs and finances, Morrison later agreed to loan Spencer the $\$ 300$, four days after final passage of the Chemical Bank charter. Further, the loan was "made in perfect good faith," which Morrison swore was "entered on his books in the ordinary course of business, and that it was given without any reference to the vote of Mr. Spencer” (New York Senate, 500).

Spencer testified to the same effect. Two of Spencer's colleagues testified that Spencer had expressed his support for the Chemical Bank's petition from the time it was introduced (ibid, 500), statements that contradict Spencer's own testimony. A committee of the assembly charged with investigating the matter concluded that Spencer was guilty of "indiscretion," but not corruption. "But," the committee continued, "they trust that his case will serve as a beacon, to warn all others under similar circumstances" (ibid, 501). Although the committee considered Spencer's decision to approach Morrison for a loan imprudent and one likely to be misconstrued, Spencer had done nothing wrong.

In addition to the charges Caldwell levied against assemblyman Spencer, he also implicated state senators Thomas Greenly (Hamilton), Perley Keyes 
(Watertown), Melancton Wheeler (Whitehall), Alvin Bronson (Oswego), John Cramer (Waterford), and Erastus Root (Delhi), president of the senate, as men benefitting from the charter (ibid, 501). After taking testimony from several politicians and lobbyists, including Thurlow Weed and Samuel Swartwout, many of whom implicated each other, the senate investigating committee considered Caldwell's charges against the senators unfounded. They concluded, despite Caldwell's production of a list of the names and specific amounts between $\$ 500$ and $\$ 2,000$ promised to each by Morrison, that none of the senators named by Caldwell benefitted directly or indirectly from the charter (ibid, 502). Yet, another director of the Chemical Bank testified that $\$ 50,000$ in shares were set aside, intended for "some member or members of the legislature" (ibid, 503). Given the source, they took this claim seriously, but found that Morrison intended these shares for his "friends" and not as inducements to support the charter. The committee also found that relatives of two senators were hired as clerks in the bank shortly after it was chartered, but found no compelling evidence of quid pro quo for their votes (ibid, 502).

The senators assigned blame for the scandal on Morrison's lobbyists, including two state judges, who broke with legislative decorum in their efforts to buy votes (ibid, 504). In the end, senate punished a single individual, the senate doorkeeper, John Bryan. Nearly everyone called to testify before the senate committee identified Bryan as a culprit, and claimed that he used his position as door-keeper to extract $\$ 1,000$ from Morrison, plus a promise that Morrison would find a place for his son in the firm's chemical factory. ${ }^{6}$ Bryan admitted to his behavior and the senate committee concluded that Bryan "made use of his official station to extort money from a fair applicant to the legislature....Such a man ... ought not to be permitted any longer to hold a station near the Senate" (ibid, 503). While the lobbyists and senators identified Bryan as the culprit, it is hard not to consider him, at least in part, a scapegoat. He may have breached his duty as door-

\footnotetext{
6 The door keeper's principal responsibility is to ensure that no one is on the floor of the senate or in the gallery that is not authorized to be there. In addition, he or she provides senators with copies of printed bills, reports, and documents, and conveys messages from the assembly. The door keeper also is charged with enforcing the rules of behavior among senators on the floor, and he or she can be assigned whatever other functions deemed appropriate by the president of the senate.
} 
keeper by allowing lobbyists access to the chamber, but it seems unlikely that he could have stopped the bribery and vote selling.

The end of the second period of bank chartering is dated at 1824 for two reasons. First, Kass (1965) argues that the 1821 constitution's extension of the franchise changed the electorate which, more importantly, changed the electorate's tolerance for vote selling, patronage, and the spoils system. The entire structure smacked of corruption and several new anti-establishment, anti-corruption parties formed to represent their interests. Second, by 1825 Van Buren had established the primacy of the Regency in the state's politics and Benton $(1856,360)$ contends that 1825 marked the "last attempt to procure bank charters by bribery." Van Buren and his lieutenants channeled the rent seeking nature of bank chartering to the direct benefit of the party. Individuals continued to reap the rewards from chartering, but once the Regency took control of chartering, rents were no longer allocated through bribery.

\subsection{The Albany Regency as a mature natural state, $1825-1838$}

To understand how the Albany Regency transformed bank chartering from one that involved bribery for individual gain to one in which individual incentives were harnessed to the party's benefit, it is instructive to consider Kass' $(1965,25)$ three types of party members: voters, backers, and zealots. Voters were those who could be counted on to vote for a party's candidates, did so publicly, and readily acknowledged doing so. Backers were those who contributed time and money to the party on behalf of candidates. Zealots were the local or state party leaders; they supervised the party hierarchy, designed its propaganda, and participated in party caucuses and conventions. A genuinely useful zealot possessed one or more of three attributes: (1) a reputation and personal relationships that would attract voters; (2) an understanding of the psychology of the local electorate with the capacity to craft messages with local appeal consistent with the party's platform; and (3) wealth. Zealots spanned the professions-land owning farmers, merchants, and manufacturers-but skilled newspaper editors and politically-connected attorneys were particularly sought after, because they possessed the second attribute. Kass $(1965,27)$ writes that attorneys were the "supple, colorless, and odorless political 
aristocracy of democratic America ... [that] with the help of the local newspaper editor ... accepted the responsibility for directing the political life of the people." Thus, Edwin Croswell grew wealthy and powerful as editor of the Albany Argus, the Regency's mouthpiece, as did Thurlow Weed, through his editorship of the opposition Albany Evening Journal (Van Deusen 1947)

The issue facing the Regency was how to make banks Republican and make the chartering process serve the Regency through the creation and distribution of rents without having it devolve into the bribery scandals that discredited factions, parties, and banks alike. How was the Regency to get banking to serve its patronage objectives? Van Buren and the Regency found the answer in the selective appointment of bank subscription commissioners. Commissions were created by the legislature and commissioners were responsible for opening subscription books and, if the shares were oversubscribed, which was common, to distribute shares among the subscribers, and to oversee initial share payments. Distributions were left to the judgment of the commissioners because part of their charge was to ensure that banks were owned by men of wealth, character, reputation, and standing within the local community. In the end, the feature of reputation and standing that mattered most was the subscriber's commitment to the party; that is, shares were distributed in proportion to whether a subscriber was voter, backer, or zealot. Share distributions were used to reward each type in different degrees as one component of the party's spoils or patronage system.

Investigations in 1837 and 1838 into the distribution of shares in newly chartered banks demonstrate how the Regency used the chartering process to reward voters, backers, and zealots. In response to charges that the shares of the Oneida Bank, the Commercial Bank of Oswego, and the Jefferson County Bank of Watertown had been inequitable in that the commissioners had distributed shares in a partisan fashion, legislative investigative committees provided detailed reports that support the charges.

Augustine Dauby, a subscription commissioner for the Oneida Bank (1836), testified that he was convinced that the shares would be oversubscribed, and expressed a concern that the Whigs, then in control of the Bank of Utica, would attempt to "wrest the power of the bank from the hands of its more immediate 
friends," meaning, of course, Bucktails (New York Senate 1837, 74). Dauby and the other commissioners instructed local party operatives to solicit subscriptions from as many Regency men as possible. If the subscribers had neither the wherewithal to pay for shares nor the inclination to hold the shares, the commissioners directed the subscribers to sign pre-printed powers of attorney in which the subscriber directed a third party to dispose of their shares after distribution. Subscribers who assigned their shares also signed a note for the initial $(10 \%)$ subscription payment, which was supplied by the third party holding the power of attorney. Within days of the distribution, the assigned shares were sold to Regency men at $2 \%$ to $10 \%$ over the issue price, the note was paid and the subscriber received the premium as a reward for lending his name to the commissioners. Through this process, the commissioners followed the letter of the law in that no individual was allowed to subscribe for or receive more than 25 shares, and that no commissioner directly profited from the sale of shares after distribution. All of the commissioners countenanced the practice, however, to "secure to themselves and their friends the control of the said bank, and at the same time to distribute as widely as possible the benefits to arise from the premium on the sale of stock" (New York Senate 1837, 3).

In addition to the Oneida Bank's subscription commissioners, the senate's investigative committee took testimony from complainants and local notables concerning the award of shares. Their testimony reveals how the party rewarded loyalists. Mulford Bond, a Utica grocer, testified that he sold his five shares after distribution and told the commissioners that he planned to do so. Why was he awarded shares? Because he had lived in Utica for 15 years, served as tax collector and leather inspector, and "had taken an active part in the political affairs, or as much so as any of the working class of people" (New York Senate 1837, 30). Hiram A. Stone was an "active partisan ... and ... entitled to stock" (ibid, 31). He was awarded four shares that he promptly sold. George F. Wicker, deputy sheriff of Oneida County, received and sold four shares. After making his case for shares based on his previous hard work on behalf of the party, William P. Cleveland was awarded five shares (ibid, 24). When one of the commissioners approached Cleveland for his proxy to vote at the first shareholder meeting, Cleveland said he planned to vote the shares himself, to which the commissioner is alleged to have said if he had known 
Cleveland would not give up his proxy, he would not have been awarded shares. Other men of character and standing in the community were denied shares because their commitment to the Regency faction was suspect (ibid, 73). If the commissioners had doubts about a man's political loyalties or his commitment to sell his shares to good Republicans, he did not receive any.

The 1836 Oneida Bank investigation provides insights into the Regency's patronage-based bank chartering system because the committee report provides complete shareholder lists for August 1836 (the initial distribution), November 1836, and February 1837. The bank's charter identifies the commissioners and the initial directors. The shareholder lists were also matched to histories of Utica City and Oneida County, which provide brief biographies of the area's notable men, to understand how the Regency allocated bank shares among the community's political and economic elite (New Century Club 1900; Anonymous 1878; Canfield and Clark 1909).

In August 1836, the Oneida Bank's 4,000 shares were originally divided between 632 shareholders. Three women were each awarded a single share; four men received just two shares. The modal allocation was 5 shares and the mean was 6.41 . Four state assemblymen and two state senators who resided in and represented Oneida County each received 10 shares. Not surprisingly, all voted for the charter (New York Assembly 1836, 974-75). Twelve men, including the 11 commissioners were awarded the legal maximum 25 shares. The non-commissioner who received 25 shares was Samuel Beardsley who was at various times a state senator, a four-term Congressman, state circuit court judge, the U.S. District Attorney for the Northern District of New York, a state Attorney General, and Chief Justice of the state supreme court (Anonymous 1878). It is hard to imagine a more politically-connected individual. In Kane's framework, Beardsley was zealot par excellence and he was rewarded as such. But like many lower-level political operatives who were awarded shares, Beardsley promptly sold his shares and probably made about $\$ 200$ for his troubles.

In November 1836, the bank's 4,000 shares were owned by just 226 shareholders. The modal shareholding remained five shares, but the median increased to eight shares and the average increased to 17.7 shares. Commissioner 
Dauby owned 204 shares and held a directorship in the bank. The distribution and subsequent sales of shares in the Oneida Bank reveal the Regency's bank-based patronage system in operation. Backers were awarded a handful of shares that they could, if they chose, sell for a small, quick profit ( $\$ 5$ to $\$ 10$ per share) without ever having put up any of their own money; or, if they chose, they could pay for their shares, receive dividends, and have preferred access to credit. Zealots received 10, 15 or 25 shares at distribution and, like backers might sell for a modest profit, or take a larger stake in the bank. Wealthy zealots took control of the bank by buying out the shares assigned to those who wanted to sell out.

If the men whose biographies appear in a history of Utica City or Oneida County, which are labeled notable men, represent a sample of likely zealots, the shareholder lists matched to notables can be used to dig a little deeper into the initial allocation and post-distribution reallocation of bank shares. Among the 86 notables, average shareholding at the distribution was 7.7 shares. In November 1836 average shareholding among notables was 13.9 shares, which increased to 15.0 shares in February 1837. Average shareholdings among non-notables declined from 5.6 shares in August 1836 to 4.5 in February 1837. Notables were initially awarded more shares and purchased shares after the distribution. Non-notables were more likely to be sellers. Panel A of Table 3 provides several parsimonious OLS and probit regressions to further explore the distribution behaviors; Panel B provides summary statistics by regression.

Column (1) reports the results of a regression of the natural log of the share distribution on commissioner and notable, both binary variables that take a value of one if the shares were awarded to a commissioner or notable. The coefficient estimates imply that commissioners received, on average, 4.33 (i.e., $\mathrm{e}^{1.467}$ ) more shares than non-commissioners and notables received 1.33 more shares than non-notables. Column (2) reports the marginal effects from a probit regression in which the dependent variable equals one if the individual awarded shares in August 1836 was no longer listed as a shareholder in February 1837. These individuals are labeled sellers. The estimated marginal effects reveal that commissioner, notables, and individuals awarded more shares were less likely to sell. Column (3) estimates the corollary regression for buyers-individuals who accumulated shares between 
August and February—and reveals the opposite effects. Commissioners and notables were more likely to acquire shares, while larger initial shareholders were significantly less likely to do so. Column (4), which includes only those 229 individuals who augmented their initial shareholders, regresses the natural logarithm of purchases on commissioners, notables, and initial distributions. Among purchasers, commissioners purchased 9.60 shares on average; notable men purchased 4.45 shares.

The regression results are fully consistent with the logic of the Regency's patronage-based bank chartering program. The Regency-dominated legislature approved charter petitions for politically favored elites and then used the share distribution process to distribute rents to party operatives and loyalists beyond the small group that would ultimately take control of the banks. Van Buren, Silas Wright, and William L. Marcy, even Thurlow Weed, embraced early nineteenth-century patronage politics and approved monetary payments for lobbying; they did not tolerate overt bribery among faction members (Spencer 1959; Van Deusen 1947, 221). Thus, Benton $(1856,360)$ could conclude, perhaps accurately, that "the last attempt to procure bank charters by bribery was made in 1825." In adopting their share distribution practice, the Regency restored political legitimacy to the chartering process and made the first move toward democratized banking.

Legislative investigations in 1838 into the initial share distribution of the Commercial Bank of Oswego and the sale of additional shares of the Jefferson County Bank of Watertown reveal that the same practices were used to reward party loyalists. Subscriptions were solicited from pro-Regency voters, backers and zealots, many of whom assigned their distributions through powers of attorney to others, who were more likely than others to receive shares (New York Assembly 1838). Voters were accommodated because, as Orville Hungerford president of the Jefferson County Bank testified, shares were distributed to and paid for by “notoriously poor" subscribers (New York Assembly 1838, 46). Backers and zealots, such as a canal toll collector (25 shares), a county court clerk (25 shares), a canal weighmaster (10 shares), and an attorney (10 shares), among other political appointees received shares in the Commercial Bank in proportion to their standing the party (ibid, 56-64). But the commissioners were not above a little nepotism; the nephew of one of the subscription commissioners was awarded 25 shares in the 
Commercial Bank. Thus, newly chartered banks were made Democratic-Republican to serve the political and economic aims of the Albany Regency.

If the Regency started down the path toward greater democratization of bank share ownership, their distribution practices reversed the decades-long trend of depoliticizing bank boards of directors. Figure 1 reveals that, between 1825 and 1838, the share of original bank directors that ever served in the assembly increased from less than $20 \%$ to about $35 \%$; the share of original bank directors that ever served in the state senate increased slightly from about $5 \%$ to $8 \%$.

Figure 4 reveals that the increased politicization of boards did not follow directly from increasing the number of politically active men as share distribution commissioners. Although the share of politically active commissioners increased somewhat during the Regency era, after 1830 the party followed the earlier trend of depoliticizing commissions. Whereas the share of politically-active commissioners reached upwards of $50 \%$ to $60 \%$ in the 1810 s, the share dropped to less than half that value in the late $1830 \mathrm{~s}$.

Figure 4

Percent of New York bank subscription commissioner to ever serve in state assembly or senate

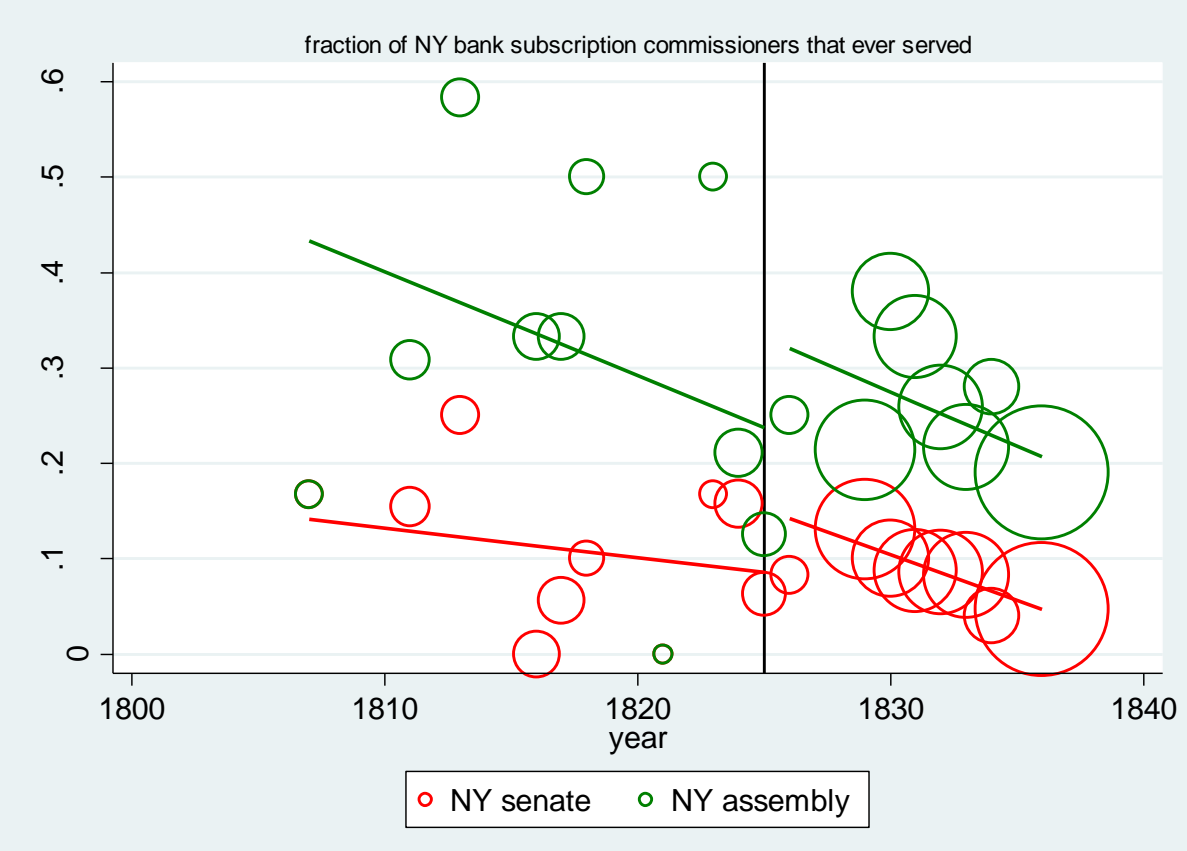


The Regency's declining use of politicians as commissions may have reflected that commissioners needed to strike a balance in their share distributions. The system could be used to benefit the party or faction currently in power, but benefitting that party or faction over the longer term sometimes meant offering shares to powerful men outside the in-group. Thus, the commissioners of the Oneida Bank denied subscriptions from most low-level Whigs and Anti-Masons, but they awarded 10 shares to Kellogg Hurlburt, who owned cotton and woolen mills and was a leading local Whig (New York Senate 1837, 86). Partisanship was one factor in determining who received shares and captured some rents, but it was not wholly determinative. Moreover, efforts by Augustine Dauby and others to keep the management of the Oneida Bank from falling under Whig control were not wholly successful. Six months after the initial distribution Hurlburt owned 80 shares and was appointed the bank's cashier (i.e., chief operating officer). The Regency could create and distribute rents through bank chartering, but a free secondary market in bank shares meant that they could not guarantee that any particular bank remained under Regency control.

\subsection{Opening access: the transition to free banking}

Although the Regency reduced the share of politically-connected commissioners in response to an electorate that was, by the mid-1830s, growing increasingly frustrated with the partisan distribution of rents, commissions continued to be made up of a majority of pro-Regency men. And, as previously documented, pro-Regency majority commissions made sure that shares were disproportionately, but not exclusively, distributed to pro-Regency voters, backers, and zealots. But changes in the electorate and voter's attitudes changed the political calculus.

Questions of power and patronage drove nearly every aspect of early nineteenth-century politics. ${ }^{7}$ Men sought appointments to all types of positionsfrom local grain inspectors, to canal lock tenders, to county sheriffs and court clerks, to judgeships, to the collector of the port of the New York City, the most lucrative

7 Van Deusen $(1947,265)$ wrote that "patronage and power were matters that were seldom absent from Weed's thinking." And regardless of whether he was serving at the state or federal level, most of the working hours of William L. Marcy's first months in office were taken up by patronage appointments (Spencer 1959, 226). 
appointed position in the state. But for every appointee there were several men that William L. Marcy labeled "disappointees," and a powerful, politically-connected disappointee might pose more of a threat to the long-term aspirations of an elected politician than an ineffectual appointee (Spencer 1959, 139, 270). Disappointed, disgruntled office seekers tended to turn on their would-be patrons. Much the same thing happened in the mid-1830s with banking policy. Disappointed bank promoters sought an alternative to the Regency's patronage-based bank chartering. Two events - the rise of the Antimasonic Party and the Panic of 1837-opened the door for change.

A critical change that predated the Antimasons and the Panic was the expansion of the franchise in the 1820s. At the Revolution, only about $10 \%$ of $\mathrm{New}$ York's free white males were eligible to vote for candidates to the colonial assembly. Between the 1777 and 1821, about one-third of the adult male population was eligible to vote. After 1821 it increased to about 85\%, and the electoral law of 1825 enfranchised all adult males who had lived in the state for 12 months and their current county of residence for six, even if they had not paid any taxes. Under popular pressure for greater representation, the parties replaced the traditional practice of nominating men for governor or federal office through the legislative caucus with the nominating convention, a change that allowed for the popular election of presidential electors. The 1824 act, moreover, redistricted the state to equalize representation. Kass $(1965,91)$ concludes that in 1825 New York was only then becoming a modern representative democracy.

In 1826 William Morgan of Batavia, New York, a bricklayer and stonecutter by trade who was bankrupted when a brewery he invested in was destroyed by a fire, disappeared after he threatened to publish a book to expose the secrets of Freemasonry. He was abducted, allegedly by a group of angry Freemasons, who drowned him in the Niagara River. Morgan's disappearance created a furor. At public meetings held throughout western New York, Masonry was condemned as an undemocratic and subversive organization that threatened public order and democracy itself. Within a year of Morgan's disappearance, Freemasonry's critics called a series of conventions and a political movement formed. The Antimasonic 
Party was born, and, although its central philosophy remained anti-freemason, it attracted voters unhappy with the Regency's spoils and patronage.

To many western New York's voters, Freemasonry's socially corrosive and politically subversive tendencies were obvious. In a region where most families were rural, owned a small farm, and belonged to an evangelical church, Freemasons were small-town professionals and merchants, who belonged to a non-evangelical church or even no church at all (Cross 1965). More troubling, however, was Freemasonry's disproportionate influence on public life. Commissioned officers in county militias were disproportionately Freemasons, as were local justices of the peace, town supervisors, and state assemblymen and senators. More than half of all legislators were Masons and 45\% of the leadership positions in the Van Buren and Clinton factions were Masons even though Masons represented only $5 \%$ of the adult male population. Kutolowski (1982) shows that Masonic overrepresentation in political service follows from their availability for office. Unlike attorneys and merchants, farmers had little spare time to devote to politics. But, in addition to their economic and political prominence, and their rejection of enthusiastic religion, the Morgan affair exposed an apparent ability to subvert justice. The Antimasonic Party demonized all Democrats, but focused its attentions on the Regency.

Whereas Benson (1961) portrays the Antimasonic base as lower-class farmers not yet integrated into the region's increasingly commercial economy, Kutolowski (1982; 1984) shows that Antimasonry's support was strongest in the region's more populous, more commercially oriented towns. Antimasonry, writes Kutolowski $(1984,281)$, "spoke most persuasively to farmers already holding relatively rich, level, improved land-farmers eager to utilize participant politics to gain further transportation improvements, [and] banking facilities." Economic dynamism and upward mobility provided the watchwords for rank-and-file Antimasons. The party's leaders were, as with the opposition, businessmen and attorneys, who speculated in land, traded in timber, produce and livestock, and wanted more banks and an expansion of the canal system.

Antimasons incorporated into the Whig Party, whose influence in New York rose in the mid-1830s in the midst of the Bank War, and the panics of 1834 and 1837. Under Thurlow Weed's direction, the opposition press across the state 
followed the Albany Evening Journal in diverting attention away from the Bank of the United States and happenings in Washington to the Regency's banking policy. One of Weed's recurrent themes was his portrayal of Albany's Regency-controlled Farmers and Mechanics Bank as the true "monster." It was well known that Farmers and Mechanics' directors extended credit to pro-Regency organizers of newly chartered banks-like the Oneida County Bank and the Commercial Bank of Oswego-to buy up shares and take control of them. The panic of 1837 led to a resounding Whig victory.

William L. Marcy, the Democratic governor, interpreted his party's defeat as a referendum on its long-standing policy of protecting the virtual monopoly of Regency-controlled banks and his annual address included a recommendation to open the business of banking. The result was the Free Banking Act, which transformed incorporated banking from a politicized legislative prerogative to a purely administrative procedure open, in theory, to any and all capable of meeting the legal requirements. Whereas 13 banks were chartered in the 1820s, 108 opened in the 1840 s and 248 in the 1850s. Free banking was not without its own problems, but it was no longer a part of the spoils and patronage system.

Bank formation in the free banking era demonstrates how the adoption of impersonal rules for forming organizations fundamentally transformed New York's institutional dynamics. Organizations appeared where previously they had been excluded. The number of banks mushroomed and increased access to credit accelerated economic and urban growth across the state Bodenhorn and Cuberes 2016; Jaremski and Rousseau 2013). Despite being challenged on legal and constitutional grounds, New York's free banking law proved to be durable (Bodenhorn and Haupert 1995). "Once open access is in place," writes Wallis (2011, 60), "going back becomes quite difficult." It was so difficult that not even judges appointed to the bench by the Bucktails were willing to overturn the law, even though it was not passed in accordance with requirements of the 1821 constitution.

It is tempting to interpret New York's 1838 free banking act as a discrete event that marks the transition from mature natural state to open access, but as Hilt (2017) notes, with respect to the incorporation of manufacturing firms, the transition was more evolutionary than revolutionary. In one respect, it is possible to observe 
the evolution even in the patronage-based chartering process. In 1830/31 New York chartered several banks in which prominent Bucktails were awarded large stakes. Benjamin F. Butler, Martin Van Buren's former law partner and Regent of the State University (1829-1832), was awarded $\$ 1,175$ in the Broome County Bank (1831), $\$ 1,000$ in the Hudson River Bank (1831), \$2,000 in the Oswego Bank (1831), and $\$ 2,000$ in the Ulster County Bank (1832). Edwin Croswell, editor of the Albany Argus, the Regency's mouthpiece, received \$3,000 in the Ulster County Bank (1832) and $\$ 4,000$ in the Canal Bank (1831), which later failed due to gross mismanagement. John A. Dix, Adjutant General of the state militia (1830-1833) and Secretary of State of New York (1833-1839), had \$2,000 in the Oswego Bank and \$1,000 in the Bank of Buffalo. William L. Marcy, U.S. senator (1831-1833) was awarded \$2,000 in the Oswego Bank and \$1,000 in the Lockport Bank (1830). Marcy's father-in-law owned \$2,575 in the Lockport Bank; and John Van Buren, Martin’s son, owned \$500 in the Ulster County Bank (New York Assembly 1831; New York Assembly 1832). In the early 1830s, Bucktail leaders enriched themselves and their families when banks were chartered. Legislators and lesser backers and zealots also took advantage of the system to line their pocketbooks.

The previously analyzed shareholder lists of the Oneida Bank (1836/37) reveal a marked change in just four years. Although the shares of the bank were directed to local backers and zealots, the only sitting members of the legislature or other prominent public officers to be awarded shares were the four assemblymen and two senators representing Oneida County. ${ }^{8}$ Each received 10 shares and three of them sold out in the first six months.

In the brief interval between 1825 and 1837 public attitudes toward politicians using the chartering system to enrich themselves changed. If Antimasons, Loco-Focos, radical Jacksonians, and Whigs could agree on anything, it was that the Regency's spoils and patronage system begged for reform. In his 1834 annual address to the legislature, Governor William L. Marcy laid out a reform program. He asked for several correctives, the most important of which included the appointment of commissioners from outside the county in which the new bank was to be located,

8 Assemblymen Henry Graves, John Hale, William Knight, and John Stryker appear in the shareholder lists, along with state senators Jared Pettibone and David Wager. 
and the disqualification of commissioners from being awarded shares (Spencer 1959, 84-85). No changes were forthcoming.

But Marcy's proposal came a decade after the first serious attempt to open access to banking in New York. In 1825 the state senate considered a bill that would have repealed the restraining acts that forbade private banking in the state- $\mathrm{a}$ first step toward free banking-but it was rejected by a partisan vote in which the then in-power Martin Van Buren (Bucktail) faction voted against it and the out-of-power De Witt Clinton faction voted in favor (New York Senate 1825). An analysis of the senate vote, however, reveals more than simple party affiliation underlying the voting blocs and the refusal of the in-group to divest itself of the political advantage to be had from the power to charter banks. Senators from the Albany district, which was an already competitive banking market with few available rents, and senators from the Binghamton-Cooperstown-Cortland district, a region that had few banks and because a majority of voters were historically anti-Van Buren was unlikely to get many more in the foreseeable future, were more likely to vote in favor of the bill.

In 1829 New York adopted the so-called Safety Fund system, one of the country's first bank liability insurance schemes. Member banks paid into an insurance pool to indemnify note holders of failed and insolvent banks. The original bill included bond-secured note issue and liberalized chartering rules, though neither feature was included in the final bill. In 1829 the Regency was not yet prepared to give up the rents that could be created and distributed to hold its coalition together. In 1838, however, a senate committee reporting on Governor Marcy's liberalization proposal was not exaggerating when it wrote that "the subject of free competition in banking has, for some time past, very much occupied the public mind." The committee continued that "although a formidable array of pecuniary and political influence has been constantly employed to subserve the interests and maintain the ascendancy of the system of exclusion ... the principles of freedom ... have constantly gained strength in the conflict" (New York Senate 1838, 2). Free banking, like open access, was not inevitable. It was made possible due to a series of purposeful and random events that made its adoption politically acceptable to a ruling elite prepared to extend the freedom to form organizations to other members of the economic elite. 


\section{Concluding remarks}

William L. Marcy (Bucktail Democrat) and Thurlow Weed (National Democrat, Antimason and Whig, by turns) were political opponents. Marcy, the conservative, was one of the Regency's most powerful men who, during a speech in the U.S. Senate said "to the victor belong the spoils of the enemy." Weed, the reformer, edited the principal anti-Regency newspaper and advocated for universal free state-supported education, free libraries, the elimination of imprisonment for debt, stricter enforcement of usury laws, temperance (but not prohibition), the better treatment of Indians and immigrants, and against the spread of slavery (but not radical abolitionism) (Van Deusen 1947). Moreover, Weed rarely let pass an opportunity to portray the Regency as a cabal that ran a corrupt political machine constructed on the dispensation of favors and patronage. Considered at face value the men could not be more different.

Yet Marcy and Weed had much in common, including their approach to politics as a system of party-based spoils. Van Buren's and Weed's tightly-knit inner circles were each made up of intelligent, loyal, hard-working, politically astute men (Van Deusen 1947, 76). Although Marcy coined the phrase, Weed took the spoils system to heart. Building an effective party required loyalty from all its operatives and one of the best ways to insure loyalty was to buy it. In nineteenth-century New York, the price of loyalty was, most often, a subordinate, typically appointive office. Packing these offices with loyal subordinates meant that the party could carry out policy. Weed learned the value of patronage through observation-Van Buren's success in the unapologetic use of it and John Quincy Adams' signal failure in his refusal to do so—and he used it at any opportunity (Watson 1941, 412).

Throughout his long career, Thurlow Weed remained an advocate of the spoils system. He did not hesitate to buy votes. He openly confessed to the practice. He was not shy about lobbying on behalf of "high questionable" bills. Among his few personally-imposed restraints was his refusal to seek favors for relatives. But the suggestion that he himself was guilty of accepting a bribe sent him into a "berserk rage" and Van Deusen $(1944,431 ; 1947,33)$ fails to uncover any evidence that Weed 
ever sold his vote on any canal, insurance, or bank bill during his short stint as Antimasonic assemblyman, even though selling one's vote, whether directly to the lobbyist or indirectly through a party's system of patronage-based chartering, could be lucrative.

And Weed, like Marcy, was troubled by the advent of Jacksonian radical democracy. In their opposition to the distribution of exclusive privileges, the enforcement of government-created monopolies, and appointive rather than elective offices, the Loco-Focos and the Working Man's Party, which considered these features of governance oppressive and unjust, threatened the very operation of New York as natural state. New York stood at the doorstep of open access in the mid1830s; conditions were right for the transition to commence, and passage of the free banking act in 1838 pushed the door ajar. But free banking was just the first step of a transition that would unfold over a longer period.

Weed opened his lobbying and vote-buying career in the early 1820 s, when he was instrumental in securing the Bank of Rochester's charter after two previously failed attempts without his services. In 1860 he was still hard at it. The 1860 legislative session was "notoriously and flagrantly corrupt" because at least a halfdozen urban transit companies competed for the rights to construct rail lines in New York City. Weed's services were actively sought after and stock broker H. A. Johnson offered Weed a one-fourth interest in the proposed Seventh Avenue and Broadway Railroad, worth an estimated $\$ 250,000$. A second projector offered to pay Weed to work against the incorporation of competing interests. The result was a block of legislation known as the "gridiron" bills vetoed by the governor and subsequently passed over the veto. Van Deusen $(1947,247)$ finds no evidence in Weed's surviving correspondence or records that he personally profited from his lobbying, but he freely admitted he worked on the projectors' behalf in return for generous contributions to William Henry Seward's presidential campaign. The contributions were never made public, but estimates vary between $\$ 50,000$ and $\$ 1$ million. The lesson from free banking to the gridiron bills is that monopolies remained valuable and the transition to open access was a process not a discrete event. 


\section{References}

Acemoglu, Daron and James A. Robinson. 2006. Economic Origins of Dictatorship and Democracy. New York: Cambridge University Press.

Alexander, DeAlva Stanwood. 1906. A Political History of the State of New York. Vol. I: 1774-1832. New York: Henry Holt and Company.

Anonymous. 1878. History of Oneida County, New York with Illustrations and Biographical Sketches of Some of Its Prominent Men and Pioneers. Philadelphia: Everts \& Fariss.

Benson, Lee. 1961. The Concept of Jacksonian Democracy: New York as a Test Case. Princeton: Princeton University Press.

Benton, Nathaniel Soley. 1856. A History of Herkimer County, Including the Upper Mohawk Valley. Albany: J. Munsell.

Bloch, Ruth H. and Naomi R. Lamoreaux. 2017. "Voluntary associations, corporate rights, and the state." NBER volume

Bodenhorn, Howard. 2006. Bank chartering and political corruption in antebellum New York: free banking as reform. In Corruption and Reform: Lessons from America's Economic History, 231-58. Edited by Edward L. Glaeser and Claudia Goldin. Chicago: University of Chicago Press.

Bodenhorn, Howard. 2011. Federal and state commercial banking policy in the Federalist era and beyond. In Founding Choices: American Economic Policy in the 1790s, 151-76. Edited by Douglas A. Irwin and Richard Sylla. Chicago: University of Chicago Press.

Bodenhorn, Howard and David Cuberes. 2016. Finance and urbanization in early nineteenth-century New York. Working paper, Clemson University.

Bodenhorn, Howard and Michael Haupert. 1995. Was there a note issue conundrum in the free banking era? Journal of Money, Credit, and Banking 27(3), 702-12.

Canfield, W. W. and J. E. Clark. 1909. Things Worth Knowing about Oneida County. Utica: Thomas J. Griffiths.

Cross, Whitney R. 1965. The Burned-Over District: The Social and Intellectual History of Enthusiastic Religion in Western New York. New York: Harper \& Row. 
Crothers, A. Glenn. 1999. Banks and economic development in post-revolutionary northern Virginia, 1790-1812. Business History Review 73(1), 1-39.

Ekelund, Robert B., Robert D. Tollison, Gary M. Anderson, F. H. Robert, and Audrey B. Davidson. 1996. Sacred trust: the medieval church as an economic firm. New York: Oxford University Press.

Goldman, Lawrence (ed.). 2008. The Federalist Papers. New York: Oxford University Press.

Hammond, Bray. 1957. Banks and politics in America from the Revolution to the Civil War. Princeton: Princeton University Press.

Hammond, Jabez. 1844. The History of Political Parties in the State of New York, from the Ratification of the Federal Constitution to December 1840. Vol. I. Cooperstown: H. \& E. Phinney.

Hildreth, Richard. 1837. The History of Banks: To which is Added a Demonstration of the Advantages and Necessity of Free Competition in the Business of Banking. Boston: Hilliard, Gray \& Company. Reprint edition. New York: Augustus M. Kelly, 1968.

Hilt, Eric. 2017. Corporation law and the shift toward open access in the antebellum United States. In Organizations, Civil Society, and the Roots of Development. Edited by Naomi R. Lamoreaux and John J. Wallis. Chicago: University of Chicago Press.

Holdsworth, John Thom. 1928. Financing an Empire: History of Banking in Pennsylvania. Chicago: S. J. Clarke Publishing Company.

Hubert, Philip G., Jr. 1903. The Merchants' National Bank of the City of New York. New York: private printing.

Hutchins, S. C. 1870. Civil List and Forms of Government of the Colony and State of New York. Albany: Weed, Parsons \& Company.

Jaremski, Matthew and Peter L. Rousseau. 2013. Banks, free banks, and US economic growth. Economic Inquiry 51(2), 1603-21.

Koyama, Mark. 2017. The long transition from a natural state to a liberal economic order. International Review of Law and Economics 47: 29-39.

Kutolowski, Kathleen Smith. 1982. Freemasonry and community in the early republic: the case for Antimasonic anxieties. American Quarterly 34(5), 543-61. 
Kutolowski, Kathleen Smith. 1984. Antimasonry reexamined: social bases of the grass-roots party. Journal of American History 71(2), 269-293.

Lamoreaux, Naomi R. and John Joseph Wallis. 2017. Introduction: Organizations, Civil Society, and the Roots of Development.

Lewis, Lawrence, Jr. 1882. A bistory of the Bank of North America, the first bank chartered in the United States. Philadelphia: J. B. Lippincott \& Co.

Lu, Qian and John Joseph Wallis. 2017. Organization, Civil Society, and the Roots of Develoment. Edited by Naomi R. Lamoreaux and John J. Wallis. Chicago: University of Chicago Press.

Moss, David A. and Sarah Brennan. 2001. Managing money risk in antebellum New York: from chartered to free banking and beyond. Studies in American Political Development 15, 138-162.

New Century Club. 1900. Outline History of Utica and Vicinity, Prepared by a Committee of the New Century Club. Utica: I. C. Childs \& Son.

New York (State). 1802-1837. Laws of the State of New-York, Passed at the __ Session, of the Legislature, Begun and Held at the City of Albany. Albany: Printer to the State.

New York (State) Assembly. 1836. Journal of the Assembly of the State of New York ... Albany: E. Croswell, Printer to the State.

New York (State) Assembly. 1838. Report of the bank commissioners relative to sundry banks, made in pursuance of a resolution of the assembly of the $16^{\text {th }}$ May, 1837. Assembly Doc. 23. Documents of the Assembly of the State of New York, Sixty-First Session 1838. Albany: E. Croswell, Printer to the State.

New York (State) Senate. 1824. Journal of the Senate of the State of New York, at Their Forty-Seventh Session. Albany: Leake and Croswell, Printers to the State.

New York (State) Senate. 1825. Journal of the Senate of the State of New York, at Their Forty-Eighth Session. Albany: E. Croswell, Printer to the State.

New York (State) Senate. 1837. Report of the majority of the select committee on...the Oneida Bank. Doc. 58. Documents of the Senate of the State of New York, at their Forty-Sixth Session. Albany: E. Croswell, Printer to the State.

New York (State) Senate. 1838. Report of the select committee on so much of the governor's message as related to the repeal of the restraining laws. Senate 
Doc. 68. Documents of the Senate of the State of New York. Vol II. Albany: E. Croswell, Printer to the State.

North, Douglass C., John Joseph Wallis and Barry R. Weingast. 2009. Violence and Social Orders: A Conceptual Framework for Interpreting Recorded Human History. New York: Cambridge University Press.

Redlich, Fritz. 1968. The Molding of American Banking. New York: Johnson Reprint Corp.

Rockoff, Hugh. 1974. The free banking era: a re-examination. Journal of Money, Credit, and Banking 6(2), 141-67.

Rolnick, Arthur and Warren W. Weber. 1983. New evidence on the free banking era. American Economic Review 73(5), 1080-1091.

Rupp, Robert O. 1988. Parties and the public good: political Antimasonry in New York reconsidered. Journal of the Early Republic 8(3), 253-79.

Schwartz, Anna Jacobson. 1947. The beginning of competitive banking in Philadelphia, 1782-1809. Journal of Political Economy 55(5), 417-31.

Selgin, George A. and Lawrence H. White. 1994. How would the invisible hand handle money? Journal of Economic Literature 32(4), 1718-49.

Smith, Adam. 1776/1827. An Inquiry into the Nature and Causes of the Wealth of Nations. Edinburgh: Thomas Nelson and Peter Brown.

Spencer, Ivor Debenham. 1959. The Victor and the Spoils: A Life of William L. Marcy. Providence: Brown University Press.

Street, Alfred Billings. 1859. The Council of Revision of the State of New York. Albany: William Gould.

Sylla, Richard, John B. Legler, and John J. Wallis 1987. Banks and state public finance in the new republic: the United States, 1790-1860. Journal of Economic History 47(2), 391-403.

Van Deusen, Glyndon G. 1944. Thurlow Weed: a character study. American Historical Review 49(3), 427-40.

Van Deusen, Glyndon G. 1947. Thurlow Weed: Wizard of the Lobby. Boston: Little, Brown \& Co. 
Wallis, John Joseph. 2011. Institutions, organizations, impersonality, and interests: the dynamics of institutions. Journal of Economic Behavior \& Organization 79( ), 48-64.

Watson, Richard L. 1941. Thurlow Weed, political boss. New York History 22(4), 411 25.

Weber. Warren E. 2006. Early state banks in the United States: how many were there and when did they exist? Journal of Economic History 66(2), 433-455.

Weise, Arthur James. 1884. The History of the City of Albany, New York: From the Discovery of the Great River in 1524, by Verrazzano, to the Present Time. Albany: E. H. Bender. 
Data Appendix. Data sources for petitioner, subscription commissioner, and director lists

\section{New York City banks [D] = full list of directors; $[\mathrm{P}]=$ presidents only.}

Beach, Moses Y. 1855. The Wealth and Biography of the Wealthy Citizens of the City of New York. New York: The Sun Office. [W 1855]

Belden, Ezekiel Porter. 1851. New-York: Past, Present, and Future; Comprising a History of the City of New-York. Fifth edition. New York: Prall, Lewis \& Co.

Chemical Bank. 1913. History of the Chemical Bank, 1823-1913. New York: Privately printed. Reprint ed. New York: Arno Press, 1980. [D]

Doggett, John Jr. 1845. The Great Metropolis: Or New York in 1845. Second Edition. New York: Directory Office. [D]

Domett, Henry W. 1884. A History of the Bank of New York, 1784-1884 Compiled from Official Records and Other Sources at the Request of the Directors. Fourth edition. New York: privately printed.

Homans, J. Smith. 1853. The Merchant's and Banker's Almanac for 1853. New York: Office of the Bankers' Magazine. [P]

Homans, J. Smith. 1857. The Merchant's and Banker's Register for 1857. New York: Derby and Jackson. [P]

Hubert, Philip G., Jr. 1903. The Merchants' National Bank of the City of New York, 18031903: A History of Its First Century Compiled from Official Records at the Request of the Directors. New York: private printing.

Jones, John F. 1805. Jones's New-York Mercantile and General Directory. New York: John F. Jones. [D]

Lanier, Henry Wysham. 1922. A Century of Banking in New York, 1822-1922. New York: Gilliss Press. [W 1822; W 1845]

Longworth, David. 1801-1842. Longworth's American Almanack, New-York Register, and City Directory. New York: D. Longworth. (1801[D], 1813[D], 1815[D], $1822-$ 23[P], 1826-27[P], 1832-33[P], 1836[P], 1842[P])

Mayo, Robert. 1837. A Chapter of Sketches on Finance. Baltimore: F. Lucas Jr. [D] 
Shoemaker, Abraham. 1809. Ming's United States Register, and New-York Pocket Almanac for the Year 1809. New York: Alexander Ming. [D]

Tanner, T. R. 1840. New York As It Is; Containing a General Description of the City of NewYork. Vol. 6. New York: T. R. Tanner. [D]

Williams, Edwin. 1835. New York As It Is; Containing and General Description of the City and Environs. New York: J. Disturnell. [D]

[Anon.] Williams, Edwin. 1840. New York As It Is; Containing and General Description of the City and Environs. New York: T. R. Tanner. [D]

Wilson, H. 1849. The Great Metropolis; Or Guide to New-York for 1849. $5^{\text {th }}$ ed. New York: Leavitt, Trow \& Co., Printers. [D]

Wilson, H. 1856. Trow's New York City Directory for the Year Ending May 1, 1857. New York: John F. Trow, Publisher. [D]

\section{Data Sources for initial bank directors}

American Exchange Bank. 1838. The Articles of Association of the American Exchange Bank. New York: Wm. H. Colyer.

Anon. 1876. History of Ontario Co., New York. Philadelphia: Everts, Ensign \& Evert.

Anon. 1878. History of Oneida County, New York. Philadelphia: Everts \& Fariss.

Anon. 1878. History of Seneca County, New York. Philadelphia: Everts, Ensign \& Everts.

Anon. 1879. History of Cattarangus Co., New York. Philadelphia: L. H. Everts.

Anon. 1879. History of Tioga, Chemung, Tompkins and Schuyler Counties, New York. Philadelphia: Everts \& Ensign.

Anon. 1880. History of Clinton and Franklin Counties, New York. Philadelphia: J. W. Lewis \& Co.

Anon. 1902. A Biographical Record of Chemung County, New York. New York: S. J. Clarke Publishing Company.

Anon. date. History of Wyoming County, N. Y., with Illustrations, Biographical Sketches, and Portraits of Some Pioneers and Prominent...

Bank of Central New York. 1838. Articles of Association of the Bank of Central New-York at Utica. Utica: R. Northway, Jr., Printer. 
Beers, Frederick W. (ed.). 1890. Gazetteer and Biographical Record of Genesee County, N.Y., 1788-1890. Syracuse: J. W. Vose \& Co.

Beauchamp, William M. 1908. Past and Present of Syracuse and Onondaga County, New York. Vol. II. New York: S. J. Clarke Publishing Co.

Cayuga County Historical Society. 1908. History of Caynga County, New York. Auburn, N. Y.: Cayuga County Historical Society.

Chemical Bank. 1913. History of the Chemical Bank, 1823-1913. New York: Privately printed. Reprint ed. New York: Arno Press, 1980.

Clearwater, Alphonso T. 1907. The History of Ulster County, New York. Kingston, N. Y.: W. J. Van Deusen.

Conover, George S. (ed.) 1893. History of Ontario County New York. Syracuse: D. Mason \& Co.

Cookinham, Henry J. 1912. History of Oneida County, New York from 1700 to the Present Time. Vol. I. Chicago: S. J. Clarke Publishing Company.

Deposite Bank. 1838. Articles of Association of the Deposite Bank of Albany. Albany: Packard, Van Benthuysen \& Co.

Domett, Henry W. 1884. A History of the Bank of New York, 1784-1884 Compiled from Official Records and Other Sources at the Request of the Directors. Fourth edition. New York: privately printed.

Doty, Lockwood Lyon. 1876. A History of Livingston County, New York, from Its Earliest Traditions, to Its Part in the War for Our Union. Geneseo: Edward E. Doty.

Frothingham. Washington. 1892. History of Fulton County. Syracuse: D. Mason \& Co.

Green. Frank Bertangue. 1886. History of Rockland County. New York: A.S. Barnes \& Co.

Hasbrouck, Frank. 1909. The History of Dutchess County New York. Poughkeepsie: S. A. Matthieu.

Hatch, Vermelle A. 1900. Illustrated History of Jamestown, Chautanqua County, New York. Jamestown, N. Y.: C. E. Bush.

Hough, Franklin Benjamin. 1854. A History of Jefferson County in the State of New York, from the Earliest Period to the Present Time. Albany: Joel Munsell.

Howell, George Rogers and John H. Munsell. 1886. History of the County of Schenectady, N. Y., from 1662 to 1886. New York: W. W. Munsell \& Co., Publishers. 
Johnson, Crisfield. 1878. A History of Washington County, New York. Philadelphia: Everts \& Ensign.

Jones's New York Mercantile and General Director. 1806. New York.

King, Moses. 1892. King's Handbook of New York City: An Outline History and Description of the American Metropolis. Boston: Moses King.

Merchants Bank. 1855. Articles of Association of the Merchants' Bank in the City of NewYork. New York: William W. Rose.

National Bank. 1856. Articles of Association of the National Bank in the City of New York. New York: Hosford \& Co.

Peck, William F. 1884. Semi-Centennial History of the City of Rochester with Illustrations and Biographical Sketches of Some of Its Prominent Men and Pioneers. Syracuse: D. Mason \& Co.

Platt, Edmund. 1905. The Eagle's History of Poughkeepsie from the Earliest Settlements, 1683 to 1905. Poughkeepsie: Platt \& Platt.

Prescott, Herbert F. 1901. The National Commercial Bank of Albany: A Brief History of Three-Quarters of a Century. Albany: Weed-Parsons Printing Co.

Ruttenber, E. M. and L. H. Clark. 1881. History of Orange County, New York with Illustrations and Biographical Sketches. Philadelphia: Everts \& Peck.

Saint Nicholas Bank. 1853. Articles of Association of the Saint Nicholas Bank in the City of New York. New York: R. C. Root \& Anthony.

Scharf, J. Thomas. 1886. History of Westchester County, New York including Morrisania, Kings Bridge, and West Farms. Vol. II. Philadelphia: L. F. Preston \& Co.

Smith, James H. 1880. History of Chenango and Madison Counties, New York. Syracuse: D. Mason \& Co.

Stiles, Henry R. (ed.) 1884. The Civil, Political, Professional and Ecclesiastical History and Commercial and Industrial Record of the County of Kings and the City of Brooklyn, N. Y. from 1683 to 1884. Vol. 1. New York: Munsell \& Co.

Sylvester, Nathaniel Bartlett. 1878. History of Saratoga County, New York. Philadelphia: Everts \& Ensign.

Tradesmens Bank. 1854. Articles of Association of the Tradesmen's Bank of the City of New York. New York: S. Raynor, Stationer. 
Weise, Arthur James. 1884. The History of the City of Albany, New York. Albany: E. H. Bender.

White, Andrew and Thomas McMullen. 1848. Special Agents' Report to the Comptroller, In Relation to the Affairs of the Canal Bank. New York (State) Comptroller's Office. Albany.

White, Truman C. 1898. Our County and Its People: A Descriptive Work on Erie County, New York. Vol. I. Boston: The Boston History Company.

Whitney, Luna M. Hammond. 1872. History of Madison County, State of New York. Syracuse: Truair, Smith \& Co.

Young, Andrew W. 1875. History of Chautauqua County, New York, from Its First Settlement to the Present Time. Buffalo: Matthews \& Warren. 


\begin{tabular}{|c|c|c|c|c|c|}
\hline \multicolumn{6}{|c|}{ Table 1} \\
\hline \multicolumn{6}{|c|}{$\begin{array}{r}\text { Original bank directors, commissioners, and petitioners by type of } \\
\text { government service } \\
\text { Panel A: directors }\end{array}$} \\
\hline years & $\begin{array}{l}\text { obs } \\
\#\end{array}$ & $\begin{array}{l}\text { Court } \\
\text { officer } \\
\%\end{array}$ & $\begin{array}{c}\text { NY } \\
\text { senate } \\
\%\end{array}$ & $\begin{array}{l}\text { NY } \\
\text { assembly } \\
\%\end{array}$ & $\begin{array}{c}\text { Congress } \\
\%\end{array}$ \\
\hline 1791-99 & 51 & 9.8 & 19.6 & 35.3 & 3.9 \\
\hline 1800-09 & 58 & 6.8 & 15.5 & 27.6 & 3.4 \\
\hline 1810-19 & 209 & 6.2 & 6.2 & 24.4 & 0.5 \\
\hline $1820-29$ & 150 & 2 & 2.7 & 20.7 & 1.3 \\
\hline 1830-39 & 526 & 0 & 4.7 & 20.2 & 0 \\
\hline $1840-49$ & 71 & 0 & 2.8 & 12.7 & 0 \\
\hline $1850-59$ & 698 & 0 & 2.4 & 11.2 & 0 \\
\hline \multicolumn{6}{|c|}{ Panel B: Subscription commissioners } \\
\hline 1800-09 & 6 & 3.33 & 16.7 & 16.7 & 0 \\
\hline $1810-19$ & 71 & 16.9 & 9.9 & 39.4 & 4.2 \\
\hline $1820-29$ & 140 & 3.5 & 12.1 & 21.4 & 1.4 \\
\hline $1830-36$ & 397 & 16.3 & 7.1 & 25.4 & 8.1 \\
\hline \multicolumn{6}{|c|}{ Panel C: Petitioners } \\
\hline 1792-99 & 5 & 0 & 0.4 & 0 & 0 \\
\hline 1800-09 & 5 & 0 & 0.4 & 0.2 & 0 \\
\hline $1810-19$ & 91 & 12.1 & 4.4 & 27.4 & 1.1 \\
\hline $1820-29$ & 14 & 14.3 & 0 & 14.3 & 0 \\
\hline $1830-36$ & 14 & 0 & 14.3 & 21.4 & 0 \\
\hline \multicolumn{6}{|c|}{$\begin{array}{l}\text { Notes: Court officers include judges and sheriffs. Congress includes U.S. } \\
\text { House and Senate. Columns } 3 \text { through } 6 \text { report the percent of director- } \\
\text { years that bank directors, subscription commissioners, and petitioners ever } \\
\text { served in that capacity. Thus, between } 1792 \text { and } 1799,9.8 \% \text { of original } \\
\text { directors (those named as directors in legislative charter) served as an } \\
\text { officer of the court before, during, or after their first year of service on a } \\
\text { bank board of directors. Subscription commissioners were appointed by } \\
\text { the legislature to supervise share subscriptions and, if a bank's capital was } \\
\text { oversubscribed, to allocate shares among subscribers. Petitioners are } \\
\text { individuals who requested a bank charter and are named as such in the } \\
\text { chartering act. } \\
\text { Sources: see text and data appendix }\end{array}$} \\
\hline
\end{tabular}




\begin{tabular}{cccc}
\hline \multicolumn{4}{c}{ Table 2 } \\
\hline $\begin{array}{c}\text { New York City bank directors' legislative service } \\
\text { Years }\end{array}$ & obs & NY & NY \\
& & senate & assembly \\
& '\# & $\%$ & $\%$ \\
$1800-09$ & 202 & 20.3 & 25.7 \\
$1810-19$ & 437 & 9.8 & 26.1 \\
$1820-29$ & 445 & 3.1 & 14.8 \\
$1830-39$ & 733 & 1.1 & 7.9 \\
$1840-49$ & 1375 & 0.7 & 6 \\
$1850-59$ & 1809 & 0.4 & 3.3 \\
\multicolumn{4}{c}{ careers. } \\
Notes: Columns 3 and 4 report the percent of bank \\
director-years that bank directors ever served in the \\
New York senate or assembly. Thus, 20.3\% of men \\
that served on a bank board between 1800 and 1809 \\
served in the state senate at some point in their \\
\multicolumn{4}{c}{ Sources: see data appendix. } \\
\hline
\end{tabular}




\begin{tabular}{|c|c|c|c|c|}
\hline \multicolumn{5}{|c|}{ Table 3} \\
\hline \multicolumn{5}{|c|}{ Determinants of share distributions and sales at Oneida Bank (1836) } \\
\hline & (1) & (2) & (3) & (4) \\
\hline \multicolumn{5}{|c|}{ Panel A: regression analyses } \\
\hline regression type & OLS & Probit & Probit & OLS \\
\hline dependent variable & $\ln ($ distribution $)$ & seller & buyer & $\ln ($ purchases $)$ \\
\hline & & $(\mathrm{dy} / \mathrm{dx})$ & $(\mathrm{dy} / \mathrm{dx})$ & \\
\hline \multirow[t]{2}{*}{ Commissioner } & 1.467 & -0.093 & 0.254 & 2.262 \\
\hline & $(0.036)^{* *}$ & $(0.160)$ & $(0.068)^{* *}$ & $(1.316)$ \\
\hline \multirow[t]{2}{*}{ Notable } & 0.286 & -0.103 & 0.116 & 1.494 \\
\hline & $(0.043)^{* *}$ & $(0.050)^{*}$ & $(0.029)^{* *}$ & $(0.616)^{*}$ \\
\hline \multirow[t]{2}{*}{$\ln$ (distribution) } & & -0.262 & -0.056 & -0.523 \\
\hline & & $(0.058)^{* *}$ & $(0.004)^{* *}$ & $(0.071)^{* *}$ \\
\hline \multirow[t]{2}{*}{ Constant } & 1.701 & 2.212 & -0.92 & -1.669 \\
\hline & $(0.016)^{* *}$ & $(0.370)^{* *}$ & $(0.075)$ & $(0.240)^{* *}$ \\
\hline F-stat / Wald chi-sq & 829.43 & 41.63 & 131.51 & 20.16 \\
\hline $\mathrm{R}$-square & 0.26 & 0.08 & 0.27 & 0.18 \\
\hline \multicolumn{5}{|c|}{ Panel B: summary statistics } \\
\hline \multirow[t]{2}{*}{ Distribution (\# shares) } & 6.413 & 6.413 & 5.84 & 5.834 \\
\hline & $(3.398)$ & $(3.398)$ & $(0.147)$ & $(5.206)$ \\
\hline \multirow[t]{2}{*}{$\ln$ (distribution) (\#shares) } & 1.763 & 1.763 & 1.194 & 0.185 \\
\hline & $(0.425)$ & $(0.425)$ & $(1.862)$ & $(2.954)$ \\
\hline \multirow[t]{2}{*}{ Commissioner (0/1) } & 0.017 & 0.017 & 0.016 & 0.035 \\
\hline & $(0.131)$ & $(0.131)$ & $(0.125)$ & $(0.184)$ \\
\hline \multirow[t]{2}{*}{ Notable $(0 / 1)$} & 0.127 & 0.127 & 0.124 & 0.179 \\
\hline & $(0.333)$ & $(0.333)$ & $(0.329)$ & $(0.384)$ \\
\hline \multirow[t]{2}{*}{ Seller $(0 / 1)$} & & 0.728 & & \\
\hline & & $(0.445)$ & & \\
\hline \multirow[t]{2}{*}{ Buyer (0/1) } & & & 0.147 & \\
\hline & & & $(0.343)$ & \\
\hline Observations & 632 & 632 & 694 & 229 \\
\hline
\end{tabular}

